\title{
Calcification and latitudinal distribution of extant coccolithophores across the Drake Passage during late austral summer 2016
}

\author{
Mariem Saavedra-Pellitero ${ }^{1,2}$, Karl-Heinz Baumann ${ }^{1,3}$, Miguel Ángel Fuertes ${ }^{4}$, Hartmut Schulz ${ }^{5}$, Yann Marcon ${ }^{1,3}$, \\ Nele Manon Vollmar ${ }^{1}$, José-Abel Flores ${ }^{4}$, and Frank Lamy ${ }^{6}$ \\ ${ }^{1}$ Department of Geosciences, University of Bremen, P.O. Box 3304 40, 28334 Bremen, Germany \\ ${ }^{2}$ School of Geography, Earth and Environmental Sciences, University of Birmingham, Birmingham B15 2TT, UK \\ ${ }^{3}$ MARUM, Center for Marine Environmental Sciences, University of Bremen, 28359 Bremen, Germany \\ ${ }^{4}$ Departamento de Geología, Universidad de Salamanca, 37008 Salamanca, Spain \\ ${ }^{5}$ Mathematisch-Naturwissenschaftliche Fakultät, University of Tübingen, Hölderlinstr. 12, 72074 Tübingen, Germany \\ ${ }^{6}$ Alfred Wegener Institute for Polar and Marine Research, Am Alten Hafen 26, 27568 Bremerhaven, Germany
}

Correspondence: Mariem Saavedra-Pellitero (msaavedr@uni-bremen.de)

Received: 13 May 2019 - Discussion started: 21 May 2019

Revised: 12 August 2019 - Accepted: 15 August 2019 - Published: 30 September 2019

\begin{abstract}
Coccolithophores are globally distributed microscopic marine algae that exert a major influence on the global carbon cycle through calcification and primary productivity. There is recent interest in coccolithophore polar communities; however field observations regarding their biogeographic distribution are scarce for the Southern Ocean (SO). This study documents the latitudinal, as well as in depth, variability in the coccolithophore assemblage composition and the coccolith mass variation in the ecologically dominant Emiliania huxleyi across the Drake Passage. Ninetysix water samples were taken between 10 and $150 \mathrm{~m}$ water depth from 18 stations during POLARSTERN Expedition PS97 (February-April 2016). A minimum of 200 coccospheres per sample were identified in the scanning electron microscope, and coccolith mass was estimated with light microscopy. We find that coccolithophore abundance, diversity and maximum depth habitat decrease southwards, marking different oceanographic fronts as ecological boundaries. We characterize three zones: (1) the Chilean margin, where $E$. huxleyi type A (normal and overcalcified) and type $\mathrm{R}$ are present; (2) the Subantarctic Zone (SAZ), where E. huxleyi reaches maximum values of $212.5 \times 10^{3}$ cells L $^{-1}$ and types B/C, C and O are dominant; and (3) the Polar Front Zone (PFZ), where E. huxleyi types $\mathrm{B} / \mathrm{C}$ and $\mathrm{C}$ dominate. We link the decreasing trend in $E$. huxleyi coccolith mass to the poleward latitudinal succession from the type A to the type B group. Remarkably, we find that coccolith mass is
\end{abstract}

strongly anticorrelated to total alkalinity, total $\mathrm{CO}_{2}$, the bicarbonate ion and $\mathrm{pH}$. We speculate that low temperatures are a greater limiting factor than carbonate chemistry in the Southern Ocean. However, further in situ oceanographic data are needed to verify the proposed relationships. We hypothesize that assemblage composition and calcification modes of E. huxleyi in the Drake Passage will be strongly influenced by the ongoing climate change.

\section{Introduction}

The carbon chemistry of the ocean has a fundamental impact on marine life. The current influx of anthropogenic $\mathrm{CO}_{2}$ into the surface ocean is causing a substantial perturbation to marine chemistry, as exhibited by variations in alkalinity, carbonate ion, saturation state or $\mathrm{pH}$ (e.g. Gattuso et al., 2011). Many organisms use dissolved inorganic carbon for photosynthesis and/or the production of calcium carbonate biominerals. Open ocean phytoplankton includes coccolithophore algae, a unicellular organism belonging to the phylum Haptophyta (Young and Bown, 1997; Young et al., 2003). Within a single coccolithophore cell there are dual pathways of carbon utilization - for photosynthesis and for biomineralization of calcium carbonate platelets, called coccoliths. Coccolithophores produce up to $\sim 40 \%$ of open ocean calcium carbonate (Poulton et al., 2013) and are re- 
sponsible for $\sim 20 \%$ of global net marine primary production (Malone et al., 2017). Therefore, how coccolithophores respond to changing oceanic conditions is of utmost importance for marine ecology and carbon cycling. The ratio between particulate organic carbon formed during photosynthesis and particulate inorganic carbon produced via calcification varies depending on species or even morphotypes within species (Blanco-Ameijeiras et al., 2016) but can also be highly influenced by environmental conditions, such as seawater $\mathrm{CO}_{2}$ concentration, total alkalinity, and phosphate concentration (Findlay et al., 2011). As climate varies, it is expected that these key conditions will change, and it is predicted that upper oceans may experience increased stratification and decreased nutrient availability in the upper photic zone (Cabré et al., 2015). How exactly coccolithophores will respond to these changes is subject to debate.

Ocean acidification and the increase in sea-surface temperature (SST) due to global warming are major concerns in polar and subpolar regions (e.g. Wassmann et al., 2011; Post et al., 2013; Freeman and Lovenduski, 2015), triggering an increasing interest in coccolithophore ecology at high latitudes (e.g. Harada et al., 2012; Dylmer et al., 2015; Balch et al., 2016; Charalampopoulou et al., 2016; Giraudeau et al., 2016; Saruwatari et al., 2016; Nissen et al., 2018; Rigual Hernández et al., 2018; Krumhardt et al., 2019). Questions remain about how coccolithophore populations will adapt to predicted changes in their environment, if at all. There is growing concern that increasing levels of $\mathrm{CO}_{2}$ in the atmosphere and the subsequent acidification of the ocean may disrupt the production of coccoliths. As more of the water column becomes undersaturated in $\mathrm{CaCO}_{3}$ in the future (Fabry et al., 2009), carbonate dissolution will be favoured over precipitation and coccolithophores may be less successful in exporting carbon to the deep ocean (Fabry et al., 2008). Additionally, any change in the global distribution and abundance of coccolithophore species relative to non-calcifying groups of phytoplankton (e.g. naked Haptophyceae cells, diatoms, etc.) will have important effects on the biogeochemical cycling of carbon and climatic feedbacks. A known positive correlation exists over long timescales between surface-ocean carbonate ion concentrations $\left[\mathrm{CO}_{3}^{2-}\right]$ and the mean coccolith mass of the associated Noelaerhabdaceae assemblage, a family of coccolithophores which includes the extant species Emiliania huxleyi (Beaufort et al., 2011). This correlation is driven by the replacement of more heavily by less heavily calcified morphotypes or species with declining $\left[\mathrm{CO}_{3}^{2-}\right]$. Although the physiological driver for this strong ecological selective pressure is not known (Beaufort et al., 2011), it may determine Noelaerhabdaceae biogeography, particularly in high latitudes, both in the past and future (Cubillos et al., 2007).

Geographical shifts in the occurrence or abundance of coccolithophores and assemblage compositions have been recently observed (e.g. Rivero-Calle et al., 2015; Krumhardt et al., 2016). Repeated sampling in the Australian sector of the Southern Ocean (SO) over the past 4 decades has shown a dramatic range expansion of E. huxleyi south of $60^{\circ} \mathrm{S}$ (Cubillos et al., 2007), where any ocean acidification effect appears to be outweighed by surface-ocean warming. Other authors also recorded a southward expansion of the habitat of $E$. huxleyi in the SO during the last 2 decades (Winter et al., 2014), although the actual cause of this latitudinal expanse is still under debate (e.g. Patil et al., 2014; Malinverno et al., 2015). Even with a temperature-driven range expansion of coccolithophores in the SO, surface-ocean carbonate chemistry is now capable of exerting a first-order control on the composition of coccolithophore assemblages as well as on overall coccolithophore calcification (Cubillos et al., 2007; Mohan et al., 2008; Beaufort et al., 2011; Freeman and Lovenduski, 2015).

With significant changes in marine species distributions already occurring, it is crucial to understand the ecosystem structure as well as the potential impact of environmental change on the provision of essential ecosystem services (O'Brien et al., 2016). In this work, we assess the potential relationship between environmental parameters and the community composition, biogeography and calcification mode of modern high-latitude coccolithophore communities across the Drake Passage. Accordingly, we calculated extant coccolithophore species numbers at different stations between 10 and $150 \mathrm{~m}$ of the water column, evaluating the coccolith mass variations in E. huxleyi. We compared these observations with in situ conductivity-temperature-depth (CTD) measurements, carbonate chemistry parameters, and to previously published Southern Ocean coccolithophore and calcification datasets.

\section{Material and methods}

\subsection{Sample preparation for scanning electron microscope analyses and coccolithophore taxonomical considerations}

Ninety-six water samples were taken at 18 stations located in the southern Chilean continental margin and across the western end of the Drake Passage (Fig. 1) from February to April 2016 during Expedition PS97 (Lamy, 2016). Seawater samples were obtained at different depths using a rosette sampler with $24 \times 12$ L Niskin bottles (Ocean Test Equipment Inc.) attached to a CTD Seabird SBE911plus device (Lamy, 2016). The bottles were fired by a SBE32 carousel. For the study of coccolithophore assemblages, four to seven samples per station, at between 10 and $150 \mathrm{~m}$ water depth, were chosen; $2 \mathrm{~L}$ of water was filtered onto a $0.45 \mu \mathrm{m}$ pore-size Polycarbonte Track-Etched Membrane, air-dried and stored over silica gel. A small part of the filter was cut out, fixed on an aluminium scanning electron microscope (SEM) stub and sputtered with gold or palladium. A specific area of the centre of the filter was analysed with a Zeiss DSM 940A SEM at the University of Bremen to determine quantitative cell counts for all 
morphotypes, species and total coccolithophore abundance at magnifications of $1000 \times, 2000 \times$ and $5000 \times$ when required. A minimum of 200 whole coccospheres per sample were counted and classified following Young et al. (2003), the revised classification of Jordan et al. (2004), and the electronic guide to the biodiversity and taxonomy of coccolithophores Nannotax 3 (http://ina.tmsoc.org/Nannotax3/index.html, last access: 20 April 2019) by Young et al. (2019).

Initially, seven different morphotypes of Emiliania huxleyi were distinguished in the study area, belonging to two main groups, types A and B (for further details, see Nannotax). These are E. huxleyi type A (var. huxleyi), type A overcalcified, type B (var. pujosiae), type B/C (var. aurorae), type $\mathrm{C}$ (var. kleijneae), type $\mathrm{R}$ and type $\mathrm{O}$ (which included specimens with an opened central area and specimens with the central area covered by a thin plate; Table 1 and Plate 1). Additionally, the degree of calcification was visually assessed while counting, which is why the terms "normal", "calcified" and "heavily calcified" are used in this work to denote some of the most robust E. huxleyi placoliths regardless of the morphotype (see Plate 1). Semiquantitative estimates of preservation were based on SEM observations on the coccolithophore assemblage. "Good" preservation implied little or no evidence of carbonate dissolution. Coccoliths with the main morphological characteristics partially altered but still identifiable at the species level were tagged as "moderate" (e.g. T elements within the taxon E. huxleyi were present). Specimens affected by strong dissolution or high fragmentation were regarded as "poor" (e.g. T elements within the taxon E. huxleyi were dissolved).

\subsection{Oceanographic data}

The CTD rosette hydrocasts during Expedition PS97 (Lamy, 2016) provided vertical water column profiles of in situ SST, salinity (SSS), density, oxygen and fluorescence (reflecting chlorophyll- $a$ concentrations; Fig. 2). According to the criteria specified by Orsi et al. (1995), different oceanographic fronts were crossed in this latitudinal transect: the Subantarctic Front (SAF) between stations PS97/036-1 and PS97/0371 and the Antarctic Polar Front (PF) at PS97/040-1 (Fig. 1). The areas between these fronts are referred to as Subantarctic Zone (SAZ), north of the SAF, the Polar Front Zone (PFZ), between the SAF and PF, and the Antarctic Zone (AZ), south of the PF.

Phosphate, nitrate and silicate contents were retrieved from the World Ocean Atlas 2013 (WOA13) $1^{\circ} \times 1^{\circ}$ grid austral summer collection (December to February; Garcia et al., 2014). Total carbon dioxide $\left(T_{\mathrm{CO}_{2}}\right)$ and total alkalinity $\left(T_{\mathrm{ALK}}\right)$ values were obtained from the Ocean Data View (ODV) global alkalinity and total dissolved carbon $1^{\circ} \times 1^{\circ}$ grid collection from the uppermost $150 \mathrm{~m}$ of the water column during austral summer (December to February; Goyet et al., 2000). Since carbonate chemistry parameters were not measured in situ and data availability in the Drake Passage and Southern Ocean is limited, the bicarbonate ion $\left(\mathrm{HCO}_{3}^{-}\right)$, carbonate ion $\left(\mathrm{CO}_{3}^{2-}\right)$, saturation state $\left(\Omega_{\mathrm{Ca}}\right)$ and $\mathrm{pH}$ were calculated (as derived variables) with ODV software version 4.6.3 (Schlitzer, 2015) using the uppermost $150 \mathrm{~m}$ of the GLODAPv2 collection (Key et al., 2015) and excluding measurements made before $1980 . \mathrm{HCO}_{3}^{-}, \mathrm{CO}_{3}^{2-}, \Omega_{\mathrm{Ca}}$ and $\mathrm{pH}$ were also calculated (for comparison purposes) using the CO2SYS.xls program for $10-20 \mathrm{~m}$ depth (Pierrot et al., 2006) and considering the interpolated values of $T_{\mathrm{ALK}}$, $T_{\mathrm{CO}_{2}}$ and nutrients as well as the in situ measurement of temperature, salinity and pressure.

The values of each of these oceanographic parameters were estimated at the location of every CTD station by interpolating the available data points. The interpolation used a triangulation-based linear method for CTD stations located within the boundaries of the available data and a nearestneighbour extrapolation method for any CTD stations located outside of the data boundaries. Latitude-longitude coordinates were projected to the Universal Transverse Mercator (zone 19E; World Geodetic System 1984) before interpolation in order to minimize the distance distortion inherent in geographic coordinates. The calculations were done in MATLAB ${ }^{\mathrm{TM}}$ using a custom function that is provided in the Supplement.

\subsection{Sample preparation and coccolith calcite estimates in light microscope}

Fifteen samples were selected in a latitudinal transect for coccolith calcite estimates between 10 and $20 \mathrm{~m}$ water depth. Sample preparation was designed and carried out at the University of Salamanca (Spain). A part of the filter (ca. one-fourth of the original Polycarbonate TrackEtched Membrane) was cut out and carefully placed into small plastic bags. Buffered water $(\mathrm{pH}=9)$ was prepared with $0.075 \mathrm{~g} \mathrm{~L}^{-1}$ of $\mathrm{Na}_{2} \mathrm{CO}_{3}, 0.1$ and $0.04 \mathrm{~g} \mathrm{~L}^{-1}$ of unflavoured gelatin ("Gold Gelatin"); $600 \mu \mathrm{L}$ of buffered water was added, and the bags were sealed consistently in a triangular shape. After $30 \mathrm{~min}$, the bags were shaken in a lab vortex for $3 \mathrm{~min}$ to ensure that coccoliths were fully detached from the filter and resuspended. Holding each bag on top of a cover slide placed on a hot plate $\left(\right.$ ca. $60^{\circ} \mathrm{C}$ ), an incision was made with a scalpel in one of the bag angles, allowing the solution to slowly drop onto the cover slide. Once the water was evaporated, the cover slip was mounted with mixture of $50 \%$ Canada balsam and $50 \%$ xylene and left in an oven $\left(40^{\circ} \mathrm{C}\right)$ for at least $24 \mathrm{~h}$. This technique ensured that coccoliths were in the same plane of focus for polarized light microscopy. The dried filter was checked for the presence or absence of coccoliths later on in the SEM of the University of Bremen (see Supplement).

In this study, a Nikon Eclipse LV100 POL polarized light microscope with a $100 \times \mathrm{H} / \mathrm{N} 2$ objective set up with circular polarization was used at the University of Salamanca. In order to determine coccolith mass and thickness, between 20 

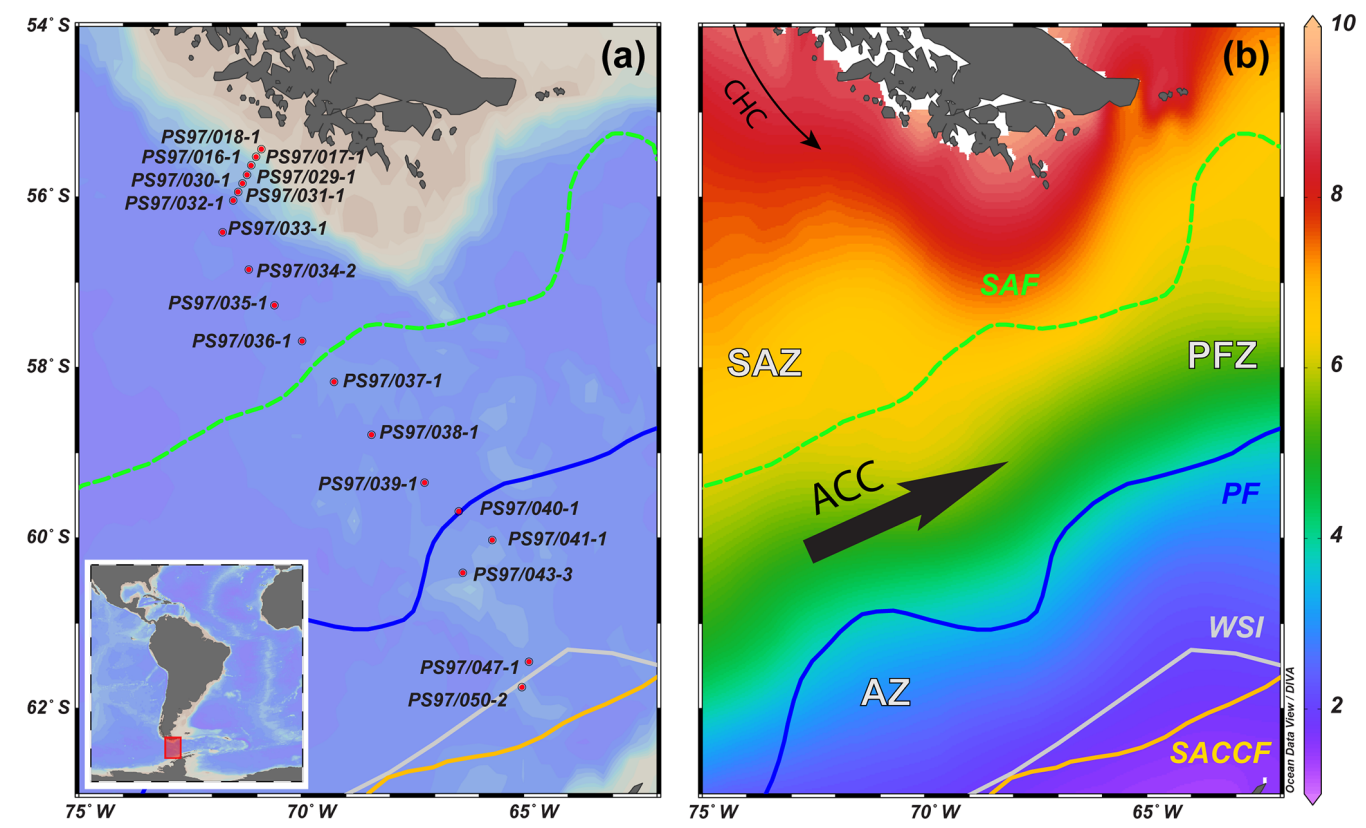

Figure 1. (a) Overview map showing the bathymetry of the Drake Passage area and the CTD stations studied; (b) sea-surface temperature $\left({ }^{\circ} \mathrm{C}\right)$ seasonal average (January, February and March) at $0 \mathrm{~m}$ water depth from the World Ocean Atlas $2013,0.25^{\circ}$ grid (Locarnini et al., 2013), plotted with Ocean Data View (ODV) software version 4.6.3 (Schlitzer, 2015). The different oceanographic fronts are indicated as follows: Subantarctic Front (SAF) with a green dashed line, Antarctic Polar Front (PF) with a blue line and southern Antarctic Circumpolar Current Front (SACCF) with a yellow line (Orsi et al., 1995). The areas between the fronts are referred to as Subantarctic Zone (SAZ), Polar Front Zone (PFZ) and Antarctic Zone (AZ). CHC is Cape Horn Current, ACC is Antarctic Circumpolar Current and WSI is winter sea ice extent (Comiso, 2003).

Table 1. Classification scheme of Emiliania huxleyi morphotypes observed in the present study (modified from Hagino et al., 2011, following Young and Westbroek, 1991, Cook et al., 2011, and Young et al., 2019).

\begin{tabular}{|c|c|c|c|c|c|}
\hline & $\begin{array}{l}\text { E. huxleyi } \\
\text { morphotype }\end{array}$ & $\begin{array}{l}\text { Morphology of the } \\
\text { distal shield }\end{array}$ & $\begin{array}{l}\text { Morphology of } \\
\text { the central area }\end{array}$ & $\begin{array}{l}\text { Distal shield } \\
\text { length }\end{array}$ & Comparable morphotypes in the literature \\
\hline \multirow{3}{*}{$\begin{array}{l}\cong \\
\stackrel{0}{0} \\
\varangle\end{array}$} & Type A & $\begin{array}{l}\text { Moderately to heavily } \\
\text { calcified elements }\end{array}$ & Grill & $<4 \mu \mathrm{m}$ & $\begin{array}{l}\text { Warm type (McIntyre and Bé, 1967), } \\
\text { var. huxleyi (Medlin et al., 1996) }\end{array}$ \\
\hline & $\begin{array}{l}\text { Type A } \\
\text { overcalcified }\end{array}$ & $\begin{array}{l}\text { Moderately to heavily } \\
\text { calcified elements }\end{array}$ & $\begin{array}{l}\text { Closed or nearly } \\
\text { closed }\end{array}$ & $<4 \mu \mathrm{m}$ & Type A overcalcified (Young et al., 2003) \\
\hline & Type R & $\begin{array}{l}\text { Reticulofenestra-like } \\
\text { heavily calcified distal } \\
\text { shield elements }\end{array}$ & $\begin{array}{l}\text { Covered or } \\
\text { nearly covered }\end{array}$ & $<4 \mu \mathrm{m}$ & $\begin{array}{l}\text { Type R (Young et al., 2003; von Dassow et } \\
\text { al., 2018) }\end{array}$ \\
\hline \multirow{4}{*}{ 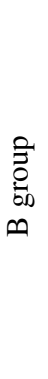 } & Type B & $\begin{array}{l}\text { Lightly calcified } \\
\text { elements }\end{array}$ & Solid plate & $\geq 4 \mu \mathrm{m}$ & $\begin{array}{l}\text { Type B (Young et al., 2003), } \\
\text { var. pujosae (Verbeek, 1990) Medlin and } \\
\text { Green in Medlin et al. (1996) }\end{array}$ \\
\hline & Type B/C & $\begin{array}{l}\text { Lightly calcified } \\
\text { elements }\end{array}$ & Solid plate & $<4 \mu \mathrm{m}$ & $\begin{array}{l}\text { Type B/C (Young et al., 2003), } \\
\text { var. aurorae (Cook, 2011) }\end{array}$ \\
\hline & Type C & $\begin{array}{l}\text { Lightly calcified } \\
\text { elements }\end{array}$ & Solid plate & $<3.5 \mu \mathrm{m}$ & $\begin{array}{l}\text { Cold type (McIntyre and Bé, 1967), } \\
\text { Type C (Young et al., 2003), } \\
\text { var. kleijniae (Medlin et al., 1996) }\end{array}$ \\
\hline & Type O & $\begin{array}{l}\text { Lightly calcified } \\
\text { elements }\end{array}$ & Opened or lamella & Variable in size & $\begin{array}{l}\text { Subarctic type (Okada and Honjo, 1973), } \\
\text { Type B (Hagino et al., 2005) }\end{array}$ \\
\hline
\end{tabular}




\section{Emiliania huxleyi type A group}
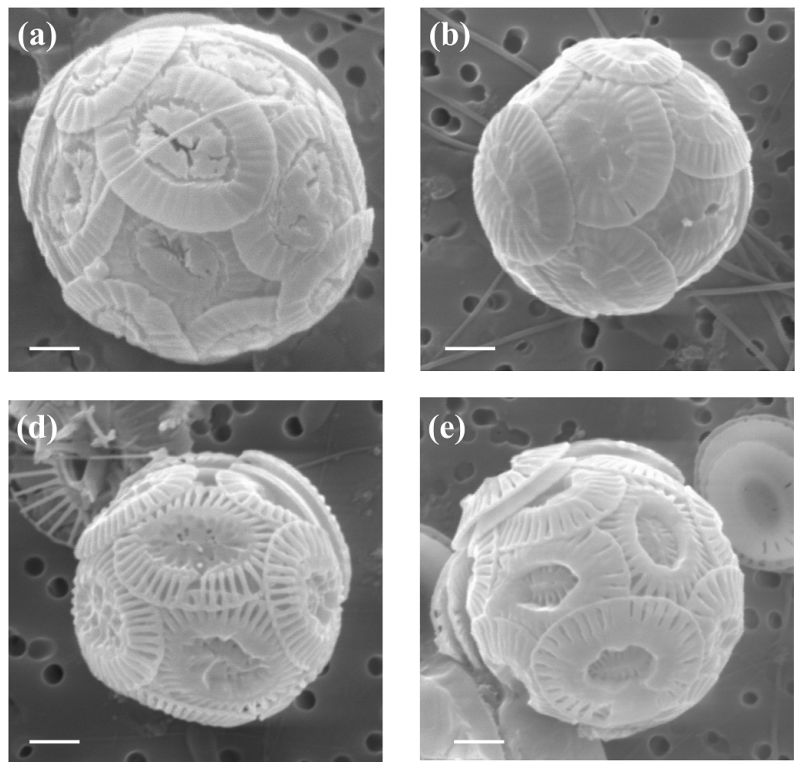

\section{Emiliania huxleyi type B group}
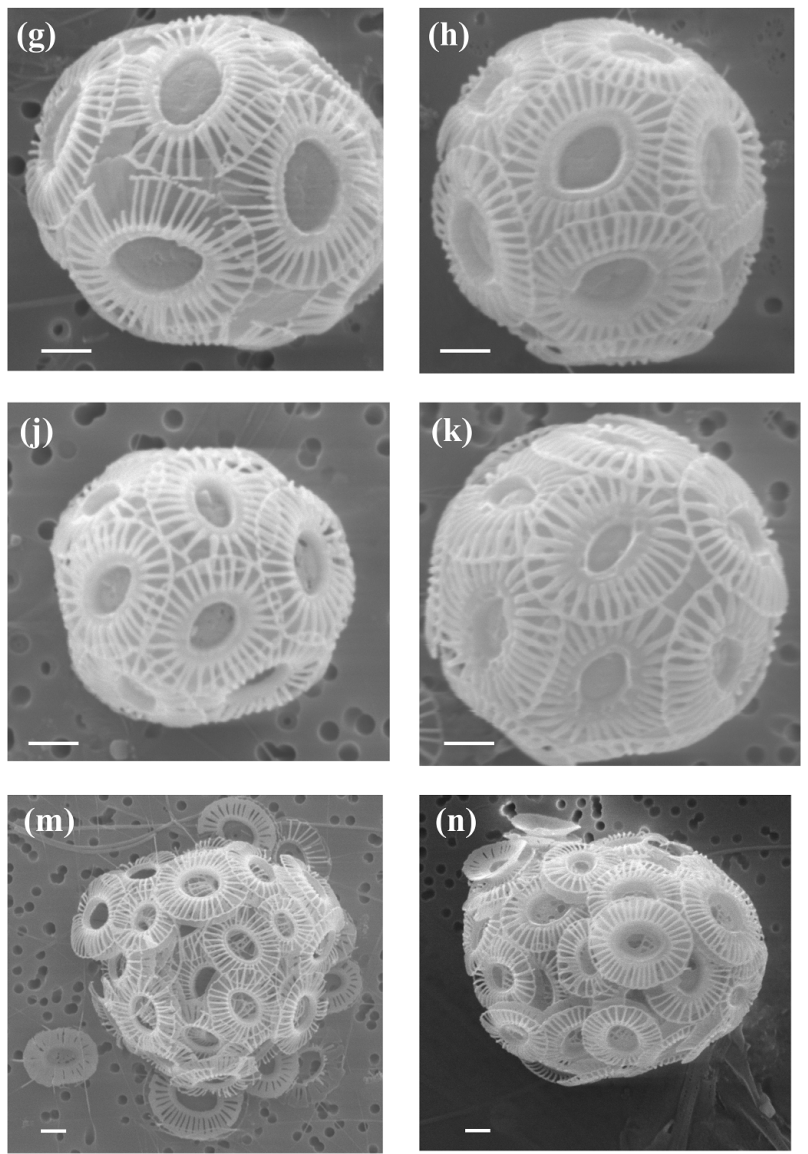
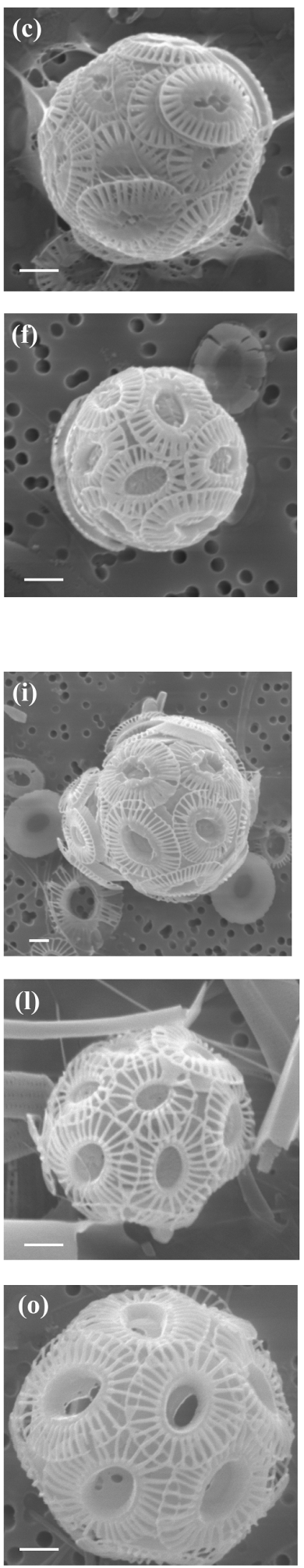

Plate 1. Specimens of Emiliania huxleyi. Group A includes (a) type R, sample PS97/018-1 at 10 m water depth; (b) type A overcalcified, PS97/018-1 at $60 \mathrm{~m}$; (c) type A overcalcified, PS97/018-1 at $100 \mathrm{~m}$; (d) type A calcified, PS97/018-1 at $60 \mathrm{~m}$; (e) type A calcified, PS97/018-1 at $20 \mathrm{~m}$; and (f) type A slightly calcified, PS97/018-1 at $60 \mathrm{~m}$. Emiliania huxleyi group B includes (g) type B, PS97/016-1 at $5 \mathrm{~m}$; (h) type B, PS97/029-1 at $60 \mathrm{~m}$; (i) type B calcified, PS97/029-1 at $150 \mathrm{~m}$; (j) type B/C, PS97/016-1 at $10 \mathrm{~m}$; (k) type B/C slightly calcified, PS97/030-1 at $150 \mathrm{~m}$; (l) type C, PS97/043-1, at $10 \mathrm{~m}$; (m) type O (opened), PS97/032-1 at $10 \mathrm{~m}$; (n) type O (lamella), PS97/038-1 at $10 \mathrm{~m}$; and (o) type O (lamella), PS97/017-1 at $60 \mathrm{~m}$. The scale bar indicates $1 \mu \mathrm{m}$. 


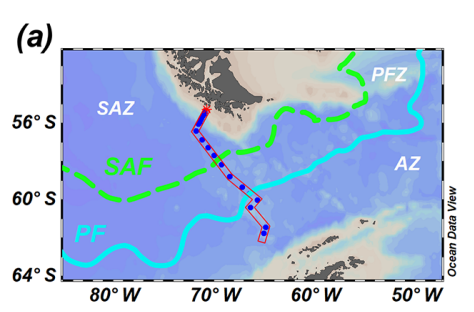

(c) Temperature $\left({ }^{\circ} \mathrm{C}\right)$

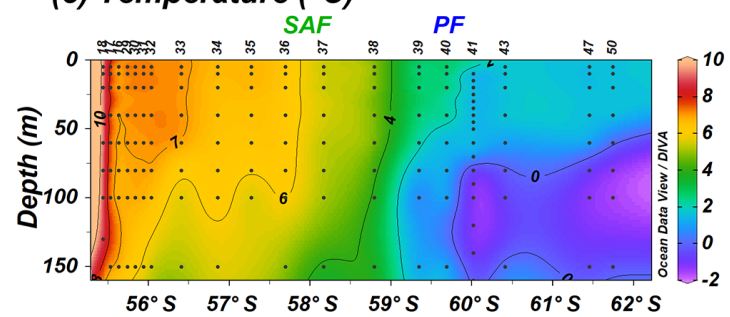

(e) Salinity (psu)

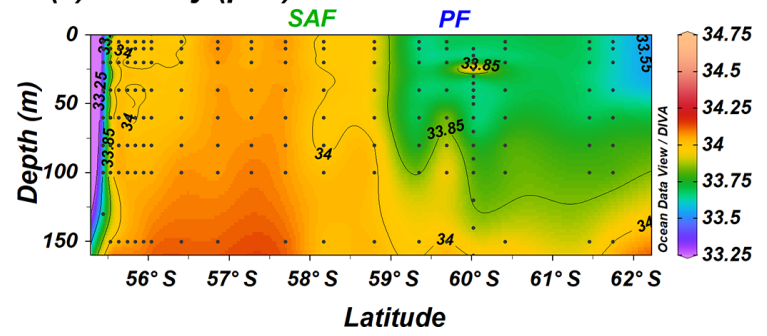

(b) Density $\left(\mathrm{kg} \mathrm{m}^{-3}\right)$

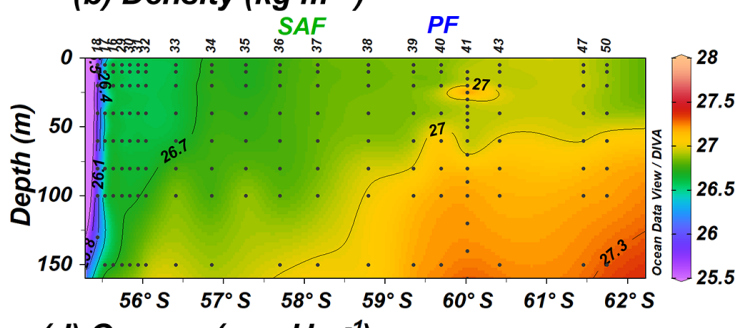

(d) Oxygen $\left(\mu \mathrm{mol} \mathrm{kg}{ }^{-1}\right)$

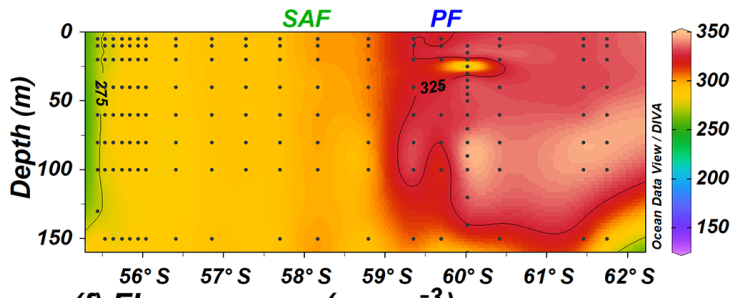

(f) Fluorescence $\left(\mathrm{mg} \mathrm{m}^{-3}\right)$

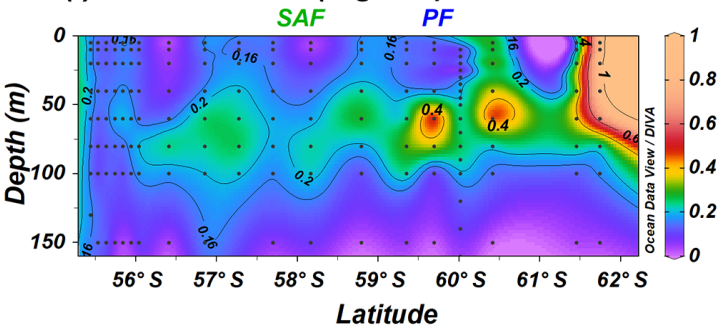

Figure 2. (a) Location of the PS97 CTD stations studied, (b) water density $\left(\mathrm{kg} \mathrm{m}^{-3}\right)$, (c) sea-surface temperature $\left({ }^{\circ} \mathrm{C}\right)$, $(\mathbf{d})$ dissolved oxygen $\left(\mu \mathrm{mol} \mathrm{kg}{ }^{-1}\right)$, (e) sea-surface salinity (psu), and (f) fluorescence $\left(\mathrm{mg} \mathrm{m}^{-3}\right)$ profiles from 55.4 to $61.7^{\circ} \mathrm{S}$ up to a depth of $150 \mathrm{~m}$. Black dots indicate sampling points. The different oceanographic fronts (according to Orsi et al., 1995) are indicated as SAF (green dashed line) and PF (blue line).

and 53 random fields of view were imaged using the Nikon DS-Fi1 digital 8 bit colour camera and the NIS-Elements software, keeping the light level of the microscope and aperture settings constant. The images were processed with the CCalcita software (for further details, see Fuertes et al., 2014). Calibration was done with images of a well-preserved and in-focus calcareous spine from the sample PS97/033-1 at $10 \mathrm{~m}$ (see Supplement). In total, 796 coccoliths were analysed, with a minimum of 34 coccoliths (up to 94) measured per sample.

\subsection{Diversity indices}

The Shannon index $(H)$, the Simpson diversity index $(1-D)$ and Fisher's alpha index were calculated with Paleontological Statistics $\left(\mathrm{PAST}^{\mathrm{TM}}\right.$ ) software version 3.22 (Hammer et al., 2001) using the raw coccolithophore counts. $H$ was determined with the following Eq. (1):

$H=-\sum_{i} \frac{n_{i}}{n} \ln \frac{n_{i}}{n}$,

where $n_{i}$ is the number of individuals in taxon $i$, and $n$ is the total number of all individuals. This index takes into account the number of individuals as well as the number of taxa. $H$ ranges from 0 for communities with just one taxon to higher values for communities with many taxa, each with few individuals (Harper, 1999). Dominance, $D$, was determined with Eq. (2):

$D=\sum_{i}\left(\frac{n_{i}}{n}\right)^{2}$.

The Simpson index $1-D$ varies from 0 to 1 and measures evenness of the community. Fisher's alpha was calculated with Eq. (3):

$S=a \cdot \ln (1+n / a)$,

where $S$ is number of taxa, $n$ is number of individuals and $a$ is Fisher's alpha.

\subsection{Statistics}

A principal component analysis (PCA) was performed on the coccolithophore relative abundance data using PAST ${ }^{\mathrm{TM}}$ software version 3.22 (Hammer et al., 2001). The objective of the PCA is to find hypothetical variables, called components, that capture the maximum proportion of the variance in the multivariate dataset when possible (Davis, 1986; 
Table 2. Summary of the coccolithophore taxa and groups in the studied plankton samples. The presence of each species in the Subantarctic Zone (SAZ), in the Polar Front Zone (PFZ) or in the Antarctic Zone (AZ) is indicated with "+" and with "-" if it is occasional. The station and water depth where the maximum number of cells per litre is recorded have also been indicated.

\begin{tabular}{|c|c|c|c|c|c|c|}
\hline Coccolithophore taxa and/or groups & SAZ & PFZ & $\mathrm{AZ}$ & $\begin{array}{r}\text { Max. } \\
\left(\text { cells } L^{-1} \text { ) }\right.\end{array}$ & Station & $\begin{array}{r}\text { Depth } \\
(\mathrm{m})\end{array}$ \\
\hline Acanthoica quattrospina & + & - & & $0.7 \times 10^{3}$ & PS97/038-1 & 10 \\
\hline Chrysotila sp. & - & & & $0.1 \times 10^{3}$ & PS97/035-1 & 100 \\
\hline Calciosolenia murrayi & + & - & & $0.3 \times 10^{3}$ & PS97/038-1 & 10 \\
\hline Calciopappus caudatus & + & - & & $5.3 \times 10^{3}$ & PS97/038-1 & 10 \\
\hline Emiliania huxleyi type B & + & - & & $7.4 \times 10^{3}$ & PS97/029-1 & 10 \\
\hline Emiliania huxleyi type B/C & + & + & - & $74.0 \times 10^{3}$ & PS97/030-1 & 150 \\
\hline Emiliania huxleyi type C & + & + & - & $103.2 \times 10^{3}$ & PS97/034-2 & 60 \\
\hline Emiliania huxleyi type $\mathrm{O}$ (including lamella) & + & + & - & $76.2 \times 10^{3}$ & PS97/036-1 & 60 \\
\hline Gephyrocapsa muellerae & + & & & $0.6 \times 10^{3}$ & PS97/018-1 & 10 \\
\hline Pappomonas spp. (including sp. 1 and 5) & + & + & & $1.4 \times 10^{3}$ & PS97/038-1 & 20 \\
\hline Syracosphaera spp. (including dilatata, corolla, marginaporata and pulchra) & + & - & & $2.8 \times 10^{3}$ & PS97/034-2 & 10 \\
\hline Wigwamma antarctica & - & + & - & $0.7 \times 10^{3}$ & PS97/034-2 & 10 \\
\hline
\end{tabular}

Harper, 1999). These new variables are linear combinations of the original variables (Hammer et al., 2001). The first principal component has the largest variance possible, and each subsequent component explains the next greatest variance possible. Samples in which fewer than 50 coccospheres were counted were excluded from the original database; therefore just 74 samples were considered for the PCA. In order to avoid skewness, the relative abundances of the different coccolithophore taxa $(x)$ were log-transformed prior to the PCA using the formula $y=\log (x+1)$. This transformation enhanced the importance of rare taxa and minimized the dominance of few abundant taxa (Mix et al., 1999), in this case that of E. huxleyi types $\mathrm{B} / \mathrm{C}$ and $\mathrm{C}$.

Seventeen coccolithophore taxa were considered for the PCA (see the taxonomical groups in Table 2). Due to the similar ecological preferences observed, Papposphaera sp. and Pappomonas spp. were lumped together in one taxonomical group in the same way as holococcolithophores, the Syracosphaera and the Ophiaster species (Table 2). In contrast, E. huxleyi morphotypes were regarded as different groups. A correlation matrix between the principal component scores and the environmental variables (i.e. SST, SSS, fluorescence, oxygen and density measured in situ as well as nitrate, phosphate and silicate contents interpolated from the WOA13) was performed in order to identify potential relationships between the environmental parameters and the coccolithophore components.

\section{Results}

\subsection{Coccolithophore distribution}

The analysis of 96 water samples shows in general higher cell concentrations in the uppermost $100 \mathrm{~m}$ of the water column in the SAZ and at shallower depths (ca. $60 \mathrm{~m}$ ) in the PFZ (Fig. 3a). The highest coccolithophore number, $214.6 \times 10^{3}$ cells $\mathrm{L}^{-1}$, is reached at station PS97/034$2(60 \mathrm{~m})$ in the SAZ, but high cell concentrations are generally observed north of the SAF (Fig. 3a). The uppermost $150 \mathrm{~m}$ average of coccolithophore concentrations drastically drops at the oceanographic fronts, from $119.9 \times 10^{3}$ to $56.4 \times$ $10^{3}$ cells $\mathrm{L}^{-1}$ (PS97/036-1, PS97/037-1) at the SAF and from $32.2 \times 10^{3}$ to $0.1 \times 10^{3}$ cells $\mathrm{L}^{-1}$ (PS97/040-1, PS97/041-1) at the PF. Stations south of the PF show very low cell numbers or are devoid of coccolithophores, but detached coccoliths are occasionally observed at the southernmost locations, even at station PS97/050-2. Coccolithophore preservation is in general moderate to good north of the PF, with optimum values at $10-20 \mathrm{~m}$, but becomes notably poorer in the AZ (Fig. 3c).

\subsection{Coccolithophore community composition}

Twenty-three different coccolithophore taxa (including morphotypes) are observed in this transect across the Drake Passage (Table 2). The most dominant species is E. huxleyi, although less abundant taxa also dwell in these subpolar or polar waters. In the following section, we will comment on 


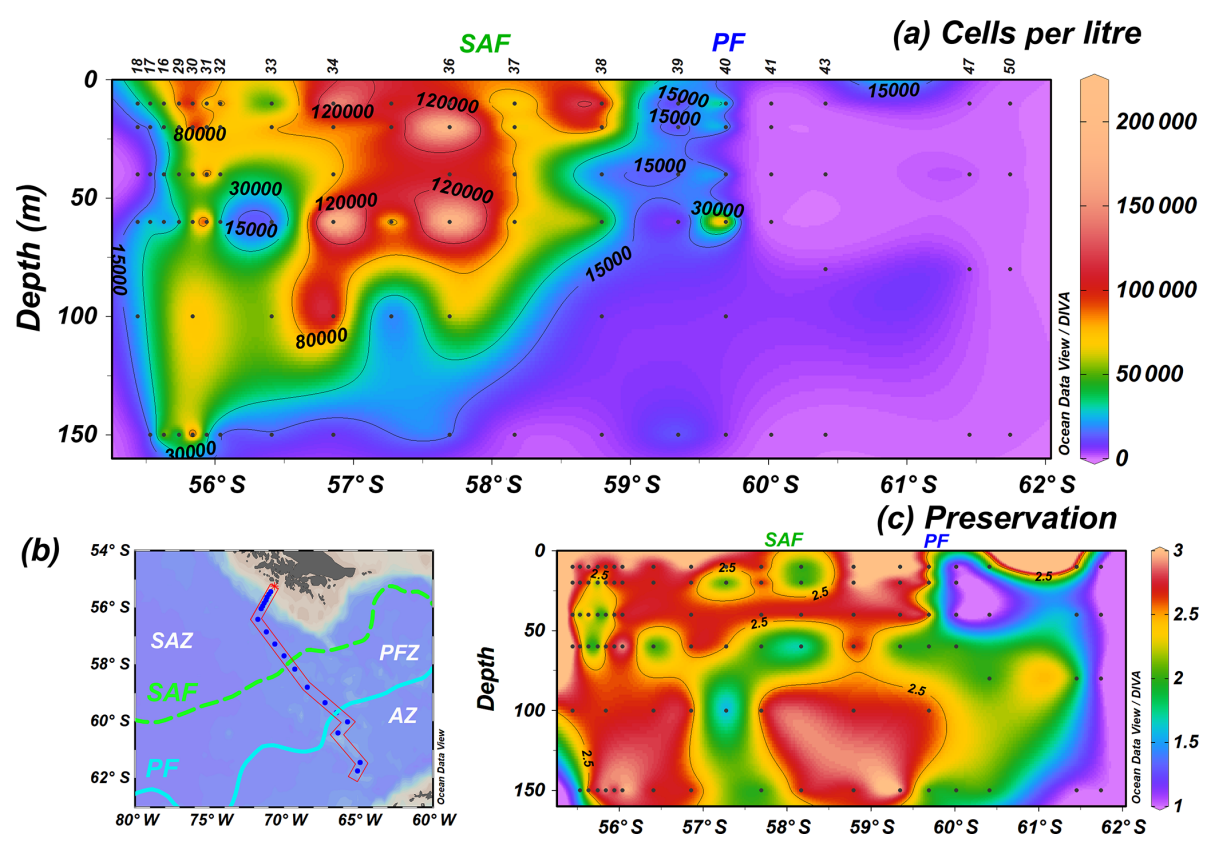

Figure 3. PS97 CTD stations showing (a) the number of coccospheres per litre across a (b) latitudinal transect in the Drake Passage and (c) semiquantitative estimates of coccolith preservation for the uppermost $150 \mathrm{~m}$ of the water column (1 is poor, 2 is moderate and 3 is good). Black dots indicate sampling points, and the different oceanographic fronts according to Orsi et al. (1995) are indicated as SAF (green dashed line) and PF (blue line).

the main species composing the coccolithophore community, from the dominant taxa to the rare ones.

\subsubsection{Emiliania huxleyi}

Emiliania huxleyi dominates the coccolithophore assemblage, reaching values up to $212.5 \times 10^{3}$ cells L $^{-1}$ at PS97/034-2 $(60 \mathrm{~m})$. This taxon is present in all the stations, except at coccolithophore-barren samples south of the PF, where coccospheres are occasionally recorded in low numbers, always below $3.0 \times 10^{3}$ cells L ${ }^{-1}$. Seven wellestablished morphotypes of $E$. huxleyi are observed; these are types A, A overcalcified, B, B/C, C, R and O (Plate 1), grouped into A (Fig. 4) and B (Fig. 5) according to Young et al. (2019). Neither malformed E. huxleyi, morphotype D, nor var. corona are present in the studied samples. However, a variation in the degree of coccolithophore calcification is observed; i.e. heavily calcified specimens as well as weakly calcified specimens are present in this transect (Table 1 and Plate 1).

The Emiliania huxleyi A group is less abundant than group B and includes type A, type A overcalcified and type R; all of them are present in coastal waters (Fig. 4a). Type R (Plate 1a) is the most uncommon E. huxleyi morphotype, and it just dwells off the shore of Chile and at station PS97/038-1 $(20 \mathrm{~m})$, where it reaches a maximum of $0.9 \times 10^{3}$ cells $\mathrm{L}^{-1}$ (Fig. 4c). A similar distribution pattern is shown by E. huxleyi type A overcalcified (Fig. 4d; Plate $1 \mathrm{~b}$ and c), with concentrations up to $1.8 \times 10^{3}$ cells L ${ }^{-1}$ at PS97/018-1 (100 m).
Emiliania huxleyi type A (normal form or moderately calcified; Plate $1 \mathrm{~d}-\mathrm{f}$ ) is restricted to the continental margin, where it records numbers of up to $1.8 \times 10^{3}$ cells L $^{-1}$ (Fig. 4 b).

Emiliania huxleyi $\mathrm{B}$ group specimens dwell north of the $\mathrm{PF}$, showing a broader distribution than A group (Fig. 5a); it includes types B, B/C, C and O. Type B (Plate $1 \mathrm{~g}-\mathrm{i}$ ) is the most unusual E. huxleyi morphotype within group B, with maximum numbers of $7.4 \times 10^{3}$ cells L $^{-1}$ at PS97/029-1 $(10 \mathrm{~m})$. Emiliania huxleyi type $\mathrm{B}$ is abundant in a narrow deep band $(0-150 \mathrm{~m})$ at the Chilean margin or open ocean transition in the SAZ, and it is occasionally present in shallow waters of the PFZ (Fig. 5b). Types B/C and C (Plate $1 \mathrm{j}-1$ ) show a broader latitudinal distribution, and they are the most abundant $E$. huxleyi taxa, with maxima of $74.0 \times 10^{3}$ cells L $^{-1}$ at PS97/030-1 $(150 \mathrm{~m})$ and $103.2 \times 10^{3}$ cells L $^{-1}$ at PS97/034$2(60 \mathrm{~m}$; Table 2 and Fig. $5 \mathrm{c}$ and d). Type B/C reaches higher concentrations at shallower depths (10-20 m) when compared to type C (20-100 m). Type O, with an "opened" central area (Plate $1 \mathrm{~m}$ ), displays a similar distribution pattern to type $\mathrm{B} / \mathrm{C}$ and reaches the highest numbers $(8.0 \times$ $10^{3}$ cells $\mathrm{L}^{-1}$ at PS97/032-1;10 m) mainly at shallow depths (10-20 m; Fig. 5e). On the contrary, type $\mathrm{O}$ with a central area covered by a thin "lamella", which is highly variable in size, is notably more abundant and dwells at deeper depths (ca. $0-100 \mathrm{~m}$ ), with maximum abundances of $72.0 \times$ $10^{3}$ cells L $^{-1}$ at PS97/036-1 (60 m; Fig. 5f). Emiliania huxleyi detached coccoliths were not counted, but their presence or absence was assessed during the SEM analyses. Free de- 
(a) E. huxleyi type A-all (cells $L^{-1}$ )

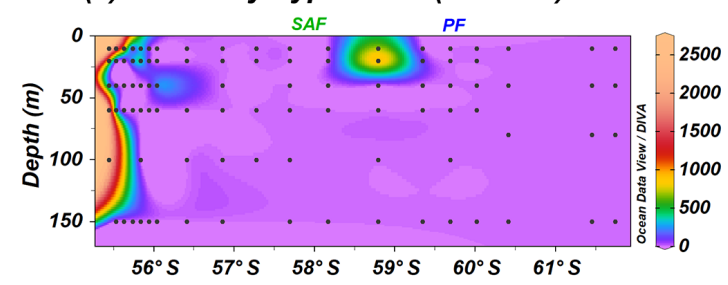

(c) E. huxleyi type $R$ (cells $L^{-1}$ )

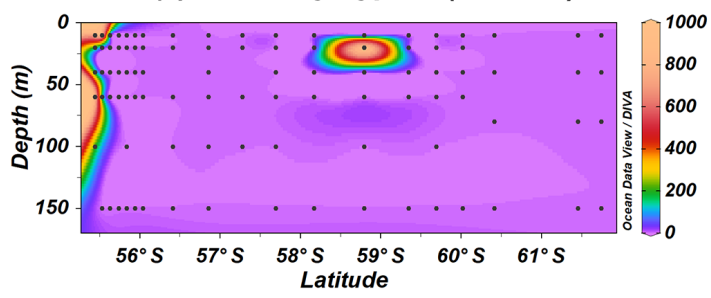

(b) E. huxleyi type A calcified (cells $L^{-1}$ )

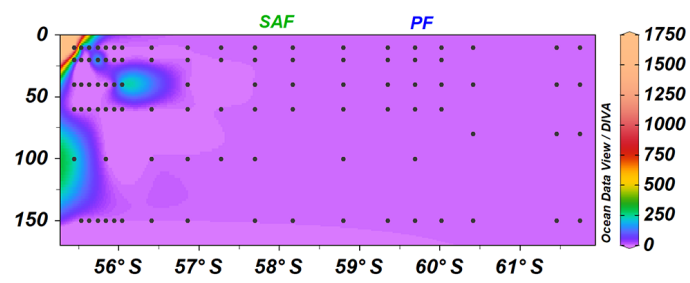

(d) E. huxleyi type A overcalcified (cells $L^{-1}$ )

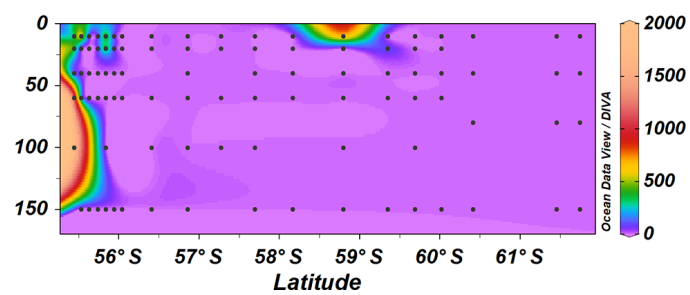

Figure 4. Location of the PS97 CTD stations studied showing the number of coccospheres per litre of (a) Emiliania huxleyi type A group, (b) E. huxleyi type A moderately calcified, (c) E. huxleyi type R and (d) E. huxleyi overcalcified. The Subantarctic Front (SAF) and the Polar Front (PF), according to Orsi et al. (1995), are indicated.

tached coccoliths of E. huxleyi types B/C-C show a broader distribution than coccospheres and are rarely recorded up to $61.7^{\circ} \mathrm{S}$ at station PS97/050-2.

\subsubsection{Other taxa}

In addition to E. huxleyi, less abundant taxa are observed. Ophiaster spp., including O. hydroideus (Plate 2) and sporadically $O$. reductus, is present primarily at the Chilean margin to a maximum of $150 \mathrm{~m}$ water depth but unexpectedly reaches up $10.1 \times 10^{3}$ cells $L^{-1}$ at PS97/038-1 at a depth of $10 \mathrm{~m}$ north of the PF (Fig. 6a). Calciopappus caudatus is found in the uppermost $60 \mathrm{~m}$ of the SAZ and PFZ, with maximum abundances of $5.3 \times 10^{3}$ cells $\mathrm{L}^{-1}$ also at PS97/038-1 (10 m; Fig. 6b). Four species belonging to the genus Syracosphaera are recorded in the Drake Passage (i.e. S. dilatata, S. corolla, S. marginaporata and S. pulchra). Syracosphaera spp. dominates among the rare coccolithophore assemblage in the SAZ, except at coastal stations, and its highest numbers (up to $5.3 \times 10^{3}$ cells $\mathrm{L}^{-1}$ PS97/038-1) are recorded between 10 and $60 \mathrm{~m}$ (Fig. 6c). In contrast, Calcidiscus s.1., mainly Calcidiscus leptoporus, displays moderate numbers at the coastal stations off the shore of Chile (from 10 to $150 \mathrm{~m}$ ) but reaches higher numbers (up to $1.4 \times 10^{3}$ cells $\mathrm{L}^{-1}$ at PS97/038-1; $10 \mathrm{~m}$ ) southwards in a rather patchy but shallow distribution (Fig. 6d). Papposphaera sp. and Pappomonas spp. (including sp. 1 and sp. 5) are observed mainly in the PFZ or at shallow depths in the SAZ, with a maximum concentration of $1.4 \times 10^{3}$ cells $\mathrm{L}^{-1}$ at PS97/038-1 $(10 \mathrm{~m}$; Fig. 6e). Holococcolithophores, mainly Syracosphaera strigilis (Plate 2), are restricted to the uppermost $60 \mathrm{~m}$ in the SAZ,

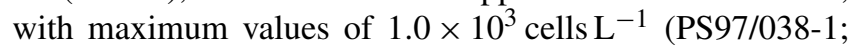
Fig. 6f).
Rare coccolithophore taxa (maximum below $0.8 \times$ $10^{3}$ cells $\mathrm{L}^{-1}$ ) are also recorded in the Drake Passage. Gephyrocapsa muellerae is restricted to the northernmost stations off the shore of Chile, while Chrysotila sp. is occasionally observed in the SAZ and Calciosolenia murrayi in the PFZ (Fig. 7c-e). Acanthoica quattrospina and Wigwamma antarctica display a broader distribution, even south of the PF, in the case of W. antarctica (Fig. 7a and b). Additionally, non-coccolithophores haptophytes belonging to the genera Petasaria and Chrysochromulina are generally present in the SAZ, PFZ and AZ, reaching maximum concentrations of $7.8 \times 10^{3}$ cells $\mathrm{L}^{-1}$ at PS97/037-1 at $60 \mathrm{~m}$ water depth (Fig. $7 \mathrm{f}$ ).

In order to investigate the relationship between the coccolithophore composition and the environmental variables in the study area, a PCA was performed using the data from 74 sampling points (Fig. 8). Based on the broken stick method, the PCA indicates the existence of three main principal components (PCs) explaining $77.4 \%$ of the total variance (see Supplement). PC1 explains $45.3 \%$ of the variance, and it is positively related to the abundance of E. huxleyi type $\mathrm{O}$ and negatively related to $E$. huxleyi type C. PC2, which is connected to E. huxleyi type $\mathrm{B} / \mathrm{C}$ and to a lesser extent to type $\mathrm{B}$, is negatively correlated to E. huxleyi type A, which accounts for $17.3 \%$ of the variance. PC1 seems associated to a marked temperature gradient. Positive PC1 values are linked to warm or moderately warm water taxa, which dwell north of the SAF, and negative PC1 values are connected to taxa that live in colder waters at higher latitudes. PC1 is correlated to SST and anticorrelated to density, oxygen content, macronutrients (phosphate and nitrate) and silicate (Table 3). PC2 is related to salinity variations (Table 3 ). Negative values of PC2 are related to extant coccolithophore taxa observed in 
(a) E. huxleyi type $B$-all (cells $L^{-1}$ )

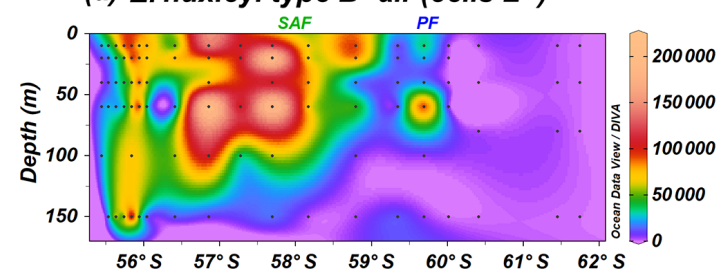

(c) E. huxleyi type $B / C$ (cells $L^{-1}$ )

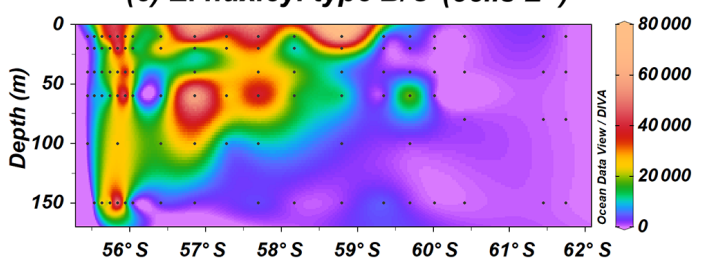

(e) E. huxleyi type O-opened (cells $L^{-1}$ )

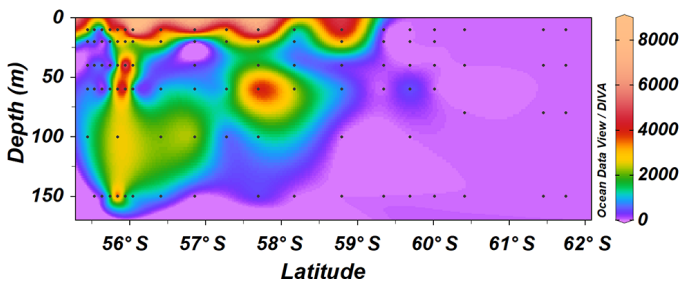

(b) E. huxleyi type B (cells $L^{-1}$ )

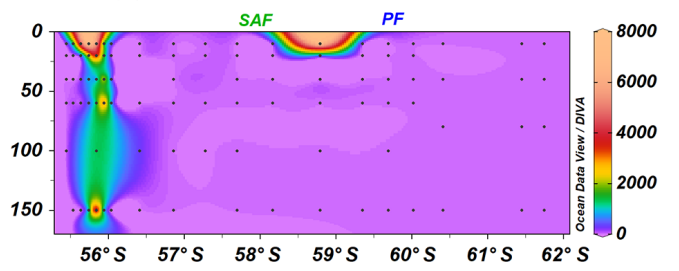

(d) E. huxleyi type C (cells $\left.L^{-1}\right)$

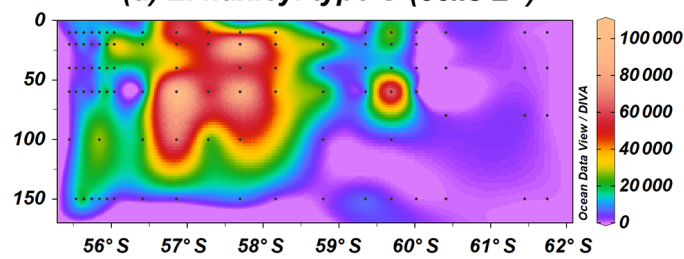

(f) E. huxleyi type O-lamella (cells $L^{-1}$ )

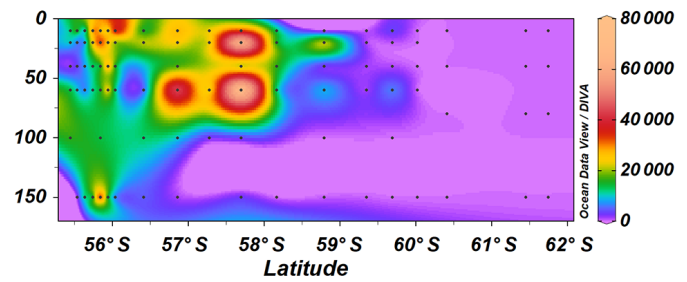

Figure 5. Location of the PS97 CTD stations studied showing the number of coccospheres per litre of (a) Emiliania huxleyi type B group, (b) E. huxleyi type B, (c) E. huxleyi type B/C, (d) E. huxleyi type C, (e) E. huxleyi type O (with opened central area), and (f) E. huxleyi type $\mathrm{O}$ (with lamella). The Subantarctic Front (SAF) and the Polar Front (PF), according to Orsi et al. (1995), are indicated.

Table 3. Correlation matrix between principal component (PC) scores and the environmental variables. Significant Pearson correlation coefficients are indicated in bold $(p<0.05)$.

\begin{tabular}{lrr}
\hline Variables & PC 1 & PC 2 \\
\hline SST & $\mathbf{0 . 7 7}$ & -0.01 \\
SSS & -0.23 & $\mathbf{0 . 6 6}$ \\
Density & $-\mathbf{0 . 7 7}$ & $\mathbf{0 . 4 1}$ \\
Oxygen & $\mathbf{- 0 . 7 0}$ & -0.02 \\
Fluorometer & -0.13 & -0.13 \\
Phosphate & $\mathbf{- 0 . 7 0}$ & -0.21 \\
Nitrate & $\mathbf{- 0 . 7 0}$ & -0.20 \\
Silicate & $\mathbf{- 0 . 6 1}$ & -0.22 \\
\hline
\end{tabular}

the low-salinity waters off the shore of Chile or to taxa living in the PFZ. On the contrary, positive values of PC2 are linked to taxa dwelling in the SAZ, where the SSS values are the highest of the studied transect. The coccolithophore assemblage composition separates out three different clusters in the PCA (Fig. 8), corresponding to three different oceanographic areas. The SAZ is characterized by positive values PC1 and PC2, the PFZ by negative PC1 and PC2 values, and the Chilean coastal environment $(\mathrm{Chl})$ by positive $\mathrm{PC} 1$ and negative PC2 values.

\subsection{Diversity}

Coccolithophore diversity indices (Shannon index $H$, Simpson index $1-D$ and Fisher's alpha) as well as the number of taxa are highest off the shore of Chile $(0-150 \mathrm{~m})$, and they became restricted to the uppermost $60 \mathrm{~m}$ in the PFZ (Fig. 9). The number of taxa is maximal at station PS97/038-1 (10 m) and drastically drops south of the PF. The Shannon and Simpson $1-D$ indices display a similar pattern (Fig. 9b and d), are highly correlated ( $r=0.95$; Supplement), and show that coccolithophore diversity decreases southwards. The number of taxa and diversity indices are strongly related to latitude (Fig. 9c and f), with station PS97/038-1 (10-20 m) being an outlier due to the high diversity estimates recorded there.

\subsection{Coccolith calcification - E. huxleyi}

Emiliania huxleyi specimens were classified into nonstandardized sub-categories (e.g. regarding level of coccolith calcification) while counting in the SEM. Specimens of type A calcified or heavily calcified and overcalcified (Fig. 10a) are present at the same locations as the common $E$. huxleyi type A (Fig. 4). Calcification in the group B implied, in most of the cases, a thicker central tube in the coccolith central area and thicker T elements (Plate 1). Although type B calcified is recorded with rather low numbers, it shows a similar distribution to type B/C calcified (Fig. 10b and c); both 
(a) Ophiaster spp. (cells $L^{-1}$ )

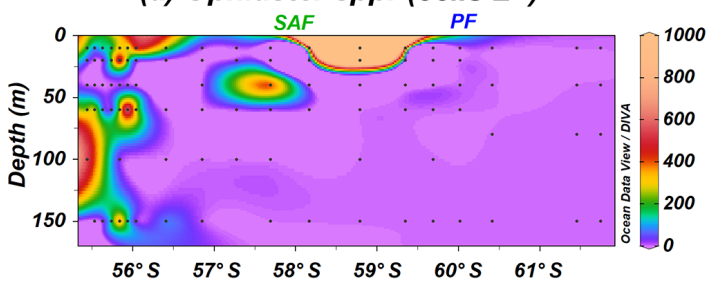

(c) Syracosphaera spp. (cells $L^{-1}$ )

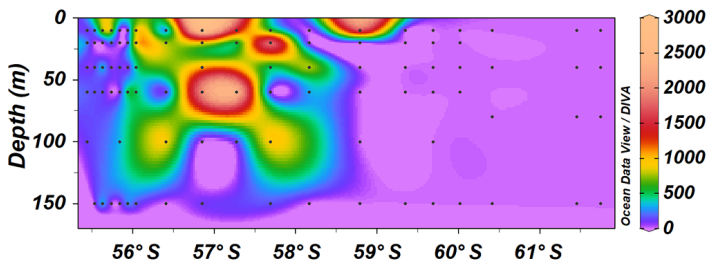

(e) Papposphaera and Pappomonas spp. (cells $L^{-1}$ (b) Calciopappus caudatus (cells $L^{-1}$ )

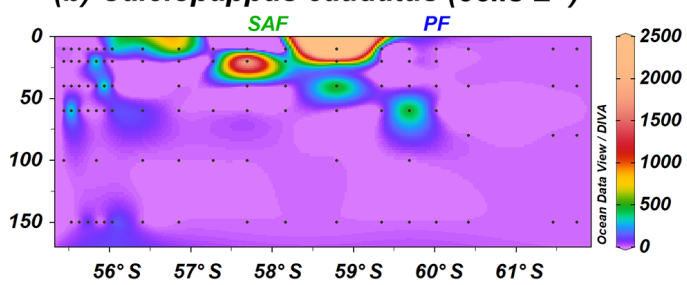

(d) Calcidiscus s.l. (cells $L^{-1}$ )

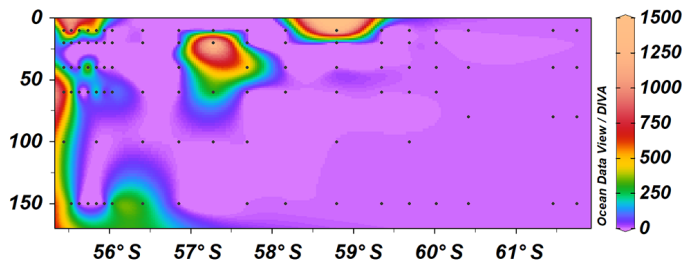

(f) Holococcolithophores (cells $L^{-1}$ )
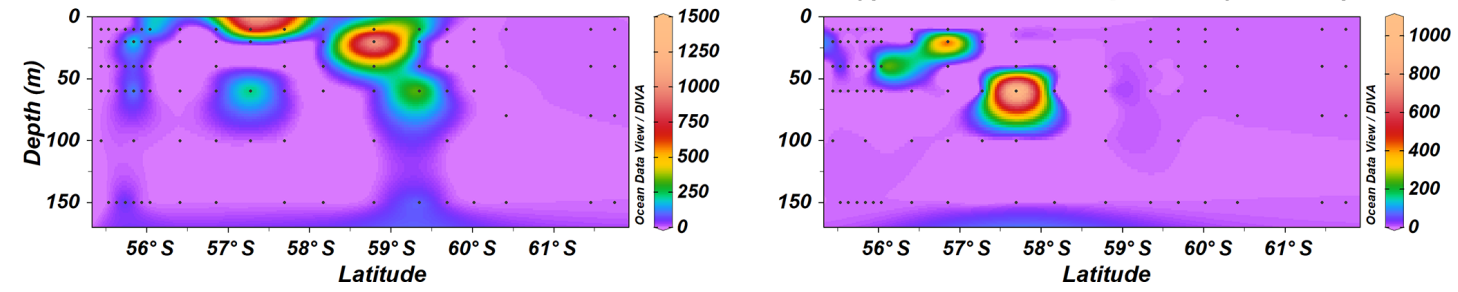

Figure 6. Location of the PS97 CTD stations studied, showing the number of coccospheres per litre of (a) Ophiaster spp., (b) Calciopappus caudatus, (c) Syracosphaera spp., (d) Calcidiscus s.l., (e) Papposphaera sp. and Pappomonas spp., and (f) holococcolithophores. The Subantarctic Front (SAF) and the Polar Front (PF), according to Orsi et al. (1995), are indicated.

are restricted to the uppermost $150 \mathrm{~m}$ of the water column at stations PS97/029-1, PS97/030-1 and PS97/031-1. Type $\mathrm{C}$ calcified is occasionally recorded where types $\mathrm{B}$ and $\mathrm{B} / \mathrm{C}$ are present but shows a much broader and patchy distribution north of the PF (Fig. 10d).

Coccolith mass measured with the software C-Calcita ranges from 19.8 to $0.8 \mathrm{pg}$, and median values (per station) vary from 7.3 to $2.4 \mathrm{pg}$. Relatively high $E$. huxleyi masses are recorded in the SAZ (Fig. 11) but not at the stations with the highest cell concentrations (such as PS97/034-2). Measurements of the coccolith mass allowed us to compare this to the identified morphotypes. In general, coccolith mass decreases southwards across the Drake Passage (Fig. 11). While high coccolith masses are reached off the shore of Chile (i.e. stations PS97/017-1 and PS97/018-1) where E. huxleyi types $\mathrm{R}$ and $\mathrm{A}$ (overcalcified) are present, low coccolith masses are reached in the $\mathrm{PFZ}$ where types $\mathrm{B} / \mathrm{C}$ and $\mathrm{C}$ dominate (i.e. stations PS97/037-1 and PS97/040-1). The gradual latitudinal mass decrease is occasionally interrupted by sudden drops in the mass estimates. These decreases in mass estimates appeared to be controlled by the predominance of a specific morphotype; for instance the low E. huxleyi mass values recorded at PS97/016-1 coincide with a sudden increase in the relative abundance of E. huxleyi type C (Fig. 11).

\section{Discussion}

\subsection{Latitudinal variations in the coccolithophore abundance, distribution and diversity}

The observed maximum coccolithophore abundance recorded (up to $214.6 \times 10^{3}$ cells $\mathrm{L}^{-1}$ ) is in agreement with previous studies carried out in different sectors of the Southern Ocean, which estimated maximum numbers between 130 and $640 \times 10^{3}$ cells L ${ }^{-1}$ (e.g. Eynaud et al., 1999; Findlay and Giraudeau, 2000; Cubillos et al., 2007; Gravalosa et al., 2008; Mohan et al., 2008; Hinz et al., 2012; Saavedra-Pellitero et al., 2014; Malinverno et al., 2015; Balch et al., 2016; Charalampopoulou et al., 2016). The coccolithophore abundance, diversity and maximum depth habitat drastically drop from north to south and portray the oceanographic fronts as ecological boundaries. Marked shifts in the coccolithophore numbers, community composition and diversity occurring at the SAF and PF observed here were also previously noted by other authors in different sectors of the Southern Ocean (e.g. Eynaud et al., 1999; Gravalosa et al., 2008; Saavedra-Pellitero et al., 2014; Malinverno et al., 2015; Balch et al., 2016; Charalampopoulou et al., 2016). Although the aforementioned studies reported increases in the abundance of coccolithophores at the SAF and PF, we only observe an increase in the 

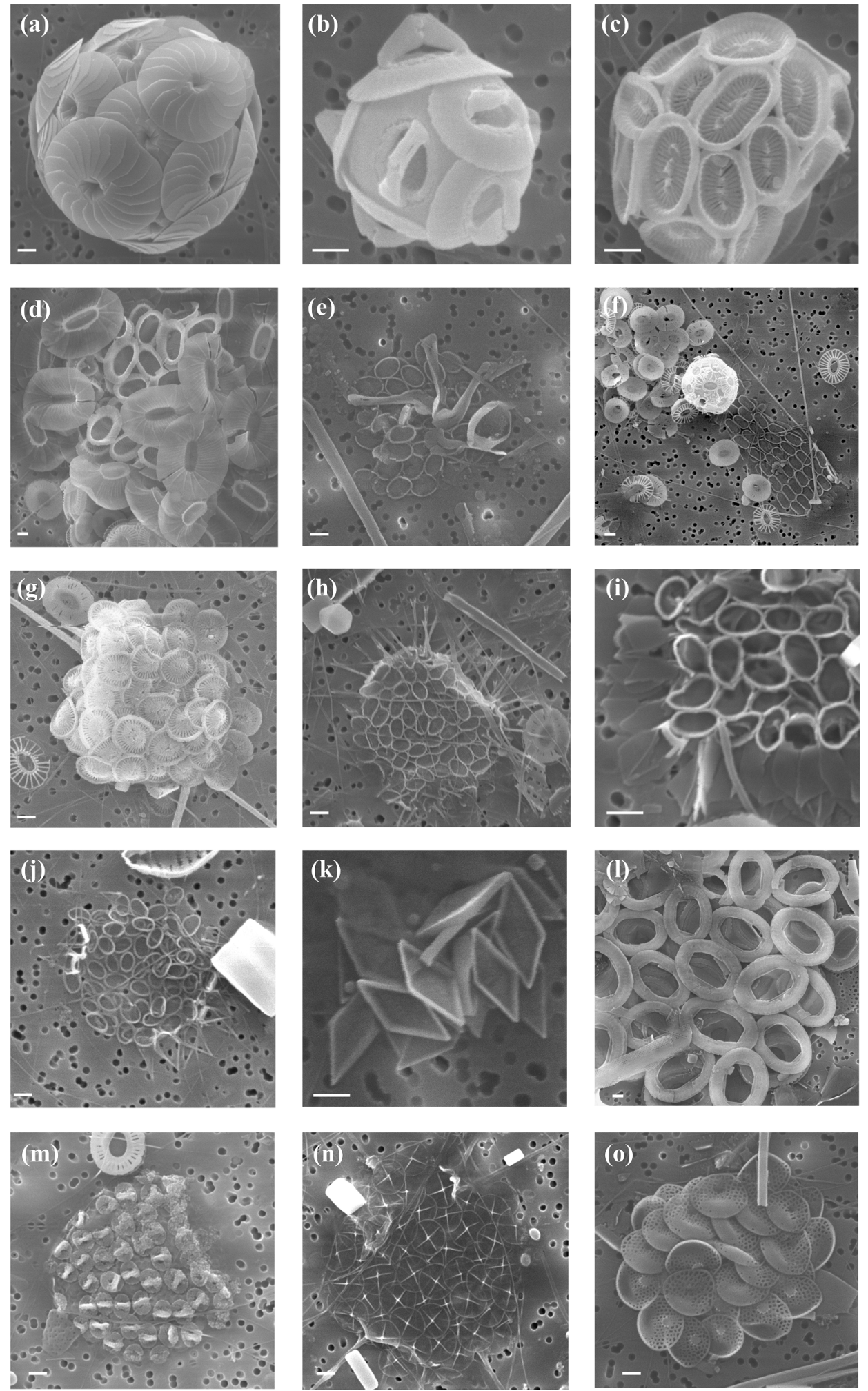

Plate 2. Other taxa present in the study area. Specimens of (a) Calcidiscus leptoporus s.s., sample PS97/016-1 at $5 \mathrm{~m}$ water depth; (b) Gephyrocapsa muellerae, PS97/018-1 at 10 m; (c) Syracosphaera dilatata, PS97/032-1 at 10 m; (d) Syracosphaera corolla, PS97/038-1 at 10 m; (e) Ophiaster hydroideus, PS97/038-1 at $10 \mathrm{~m}$; (f) Calciopappus caudatus and Emiliania huxleyi, PS97/034-2 at 10 m; (g) Acanthoica quattrospina, PS97/032-1 at $10 \mathrm{~m}$; (h) Papposphaera sagitiffera sp., PS97/038-1 at $20 \mathrm{~m}$; (i) Papposphaera cf. heldalii, PS97/030-1 at 40 m; (j) Wigwamma antarctica, PS97/039-1 at 10 m; (k) Calciosolenia sp., PS97/038-1 at 10 m; (l) Chrysotila sp., PS97/035-1 at 100 m; (m) Syracosphaera strigilis holococcolithophore phase, PS97/017-1 at 40 m; (n) Chrysochromulina sp.; and (o) Petasaria heterolepis sp., PS97/038-1 at $40 \mathrm{~m}$. The scale bar indicates $1 \mu \mathrm{m}$. 
(a) Acanthoica quattrospina (cells $L^{-1}$ )

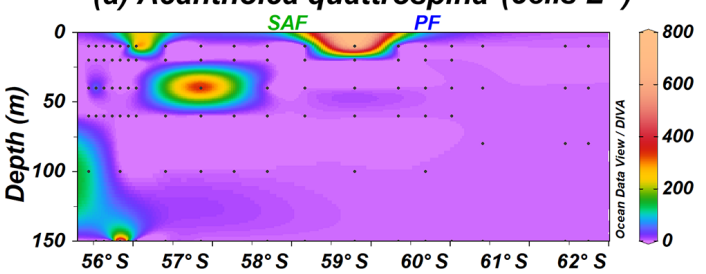

(c) Gephyrocapsa muellerae (cells $L^{-1}$ )

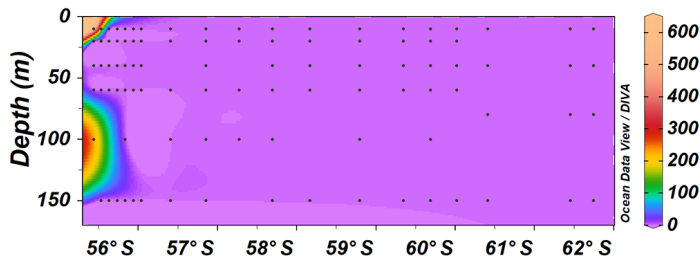

(e) Chrysotila sp. (cells $L^{-1}$ )

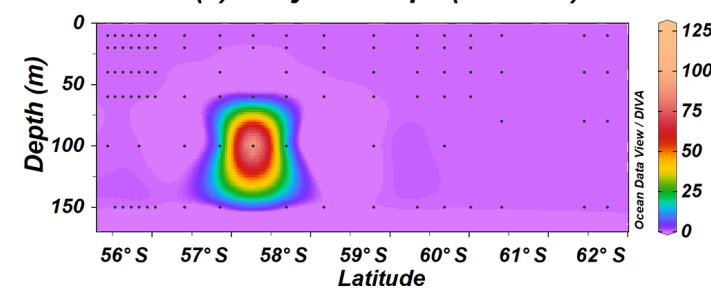

(b) Wigwamma antarctica (cells $L^{-1}$ )

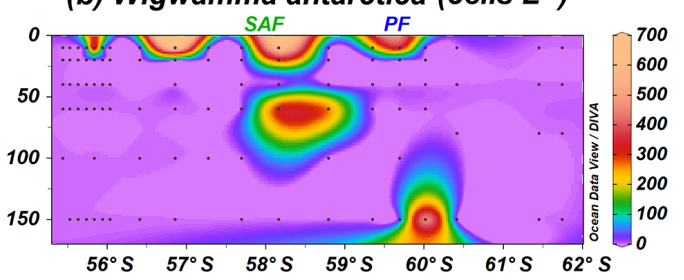

(d) Calciosolenia murrayi (cells $L^{-1}$ )

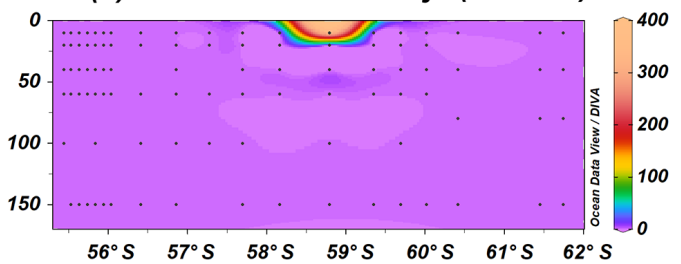

(f) Petasaria and Chrysochromulina spp. (cells $\left.L^{-1}\right)$

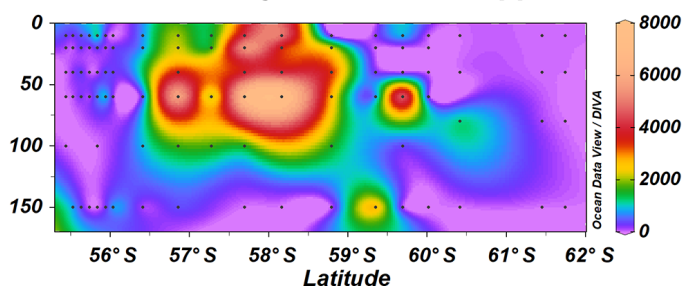

Figure 7. Location of the PS97 CTD stations studied, showing the number of coccospheres per litre of (a) Acanthoica quattrospina, (b) Wigwamma antarctica, (c) Gephyrocapsa muellerae, (d) Calciosolenia murrayi, (e) Chrysotila sp., and (f) Petasaria and Chrysochromulina spp. The Subantarctic Front (SAF) and the Polar Front (PF), according to Orsi et al. (1995), are indicated.

number of cells per litre in the PF at shallow depths $(<60 \mathrm{~m}$; Fig. 3), which is not so evident in the SAF. The increase in coccolithophore abundance recorded in the PF could be linked to the high biological productivity occurring at the Antarctic Circumpolar Current (ACC) fronts (e.g. Murphy, 1995; Pollard et al., 2002; Patil et al., 2013) due to the frontal dynamics itself (e.g. Laubscher et al., 1993) or to the physical accumulation of particulate matter and nutrients at these convergence zones (e.g. Franks, 1992; Eynaud et al., 1999; Gravalosa et al., 2008; Balch et al., 2016).

The southernmost extent of E. huxleyi has been extensively discussed (e.g. Winter et al., 2014; Malinverno et al., 2015). The PF constitutes a natural sharp barrier which marks a drop in coccolithophore diversity and number of coccospheres (Saavedra-Pellitero et al., 2014; Saavedra-Pellitero and Baumann, 2015). Several studies observed the absence of E. huxleyi south of the PF (e.g. Verbeek, 1989; Charalampopoulou et al., 2016). However, specimens of E. huxleyi and $W$. antarctica are sporadically recorded south of the PF in the studied transect, with numbers $<3 \times 10^{3}$ cell $^{-1}$ in the uppermost $80 \mathrm{~m}$ of the water column at stations PS97/043-3 and PS97/047-1. Emiliania huxleyi is observed in low numbers at temperatures between 1.7 and $-0.7^{\circ} \mathrm{C}$ (Fig. 2), below the $2{ }^{\circ} \mathrm{C}$ isotherm limit that McIntyre and Bé (1967) originally established for the Atlantic Southern Ocean. Although it is unusual, a few authors occasionally found E. huxleyi also dwelling in cold waters $<2{ }^{\circ} \mathrm{C}$ (see Table 1 in Holligan et al., 2010). Monospecific assemblages of E. huxleyi have been also recorded south of the PF by other authors in the Pacific sector (e.g. Gravalosa et al., 2008; Saavedra-Pellitero et al., 2014), Australian sector (e.g. Nishida, 1986; Findlay and Giraudeau, 2000; Cubillos et al., 2007; Malinverno et al., 2015), Atlantic sector (e.g. Eynaud et al., 1999; Holligan et al., 2010) and Indian sector (e.g. Mohan et al., 2008; Patil et al., 2014). We speculate that the free detached coccoliths of E. huxleyi observed in our study area, down to $61.7^{\circ} \mathrm{S}$ and showing a broader distribution than coccospheres, are not in situ and could have been transported. In any case the southernmost extent of coccolithophores is also influenced by the clear dominance of diatoms south of the PF, as suggested by the high diatom concentration (valves per gram of dry sediment) and biogenic opal content recorded in surface sediment samples from the AZ of the Drake Passage (Cárdenas et al., 2018) and from Pacific Southern Ocean extant plankton studies (e.g. Saavedra-Pellitero et al., 2014; Malinverno et al., 2016).

The number of taxa and coccolithophore diversity decreases southwards (Fig. 9), in agreement with other studies performed in the Drake Passage and the Australian and Pacific sectors of the Southern Ocean (e.g. Findlay and Giraudeau, 2000; Gravalosa et al., 2008; Saavedra-Pellitero et al., 2014; Charalampopoulou et al., 2016). Coccolithophore 


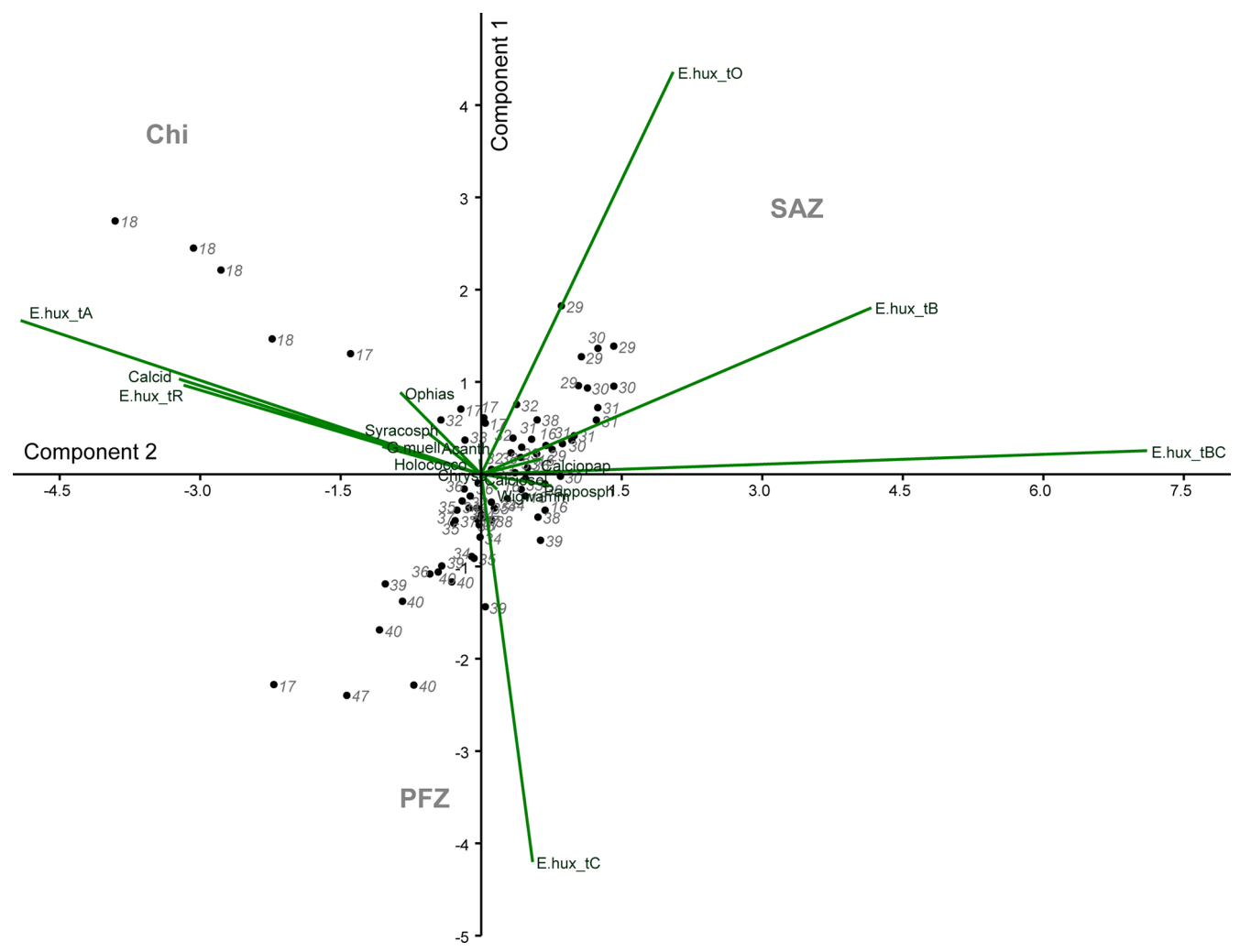

Figure 8. Principal component analysis (PCA) biplot performed on the coccolithophore dataset. The two main components (PC1 - $y$ axis and PC2 $-x$ axis), coccolithophore taxa, station numbers and the different clusters are indicated. The following abbreviations are used in the figure: E.hux_tA (E. huxleyi type A), E.hux_tB (E. huxleyi type B), E.hux_tBC (E. huxleyi type B/C), E.hux_tC (E. huxleyi type C), E.hux_tO (E. huxleyi type O), E.hux_tR (E. huxleyi type R), Calcid (Calcidiscus s.1.), Acanth (Acanthoica quattrospina), Calciopap (Calciopappus caudatus), Calciosol (Calciosolenia murrayi), Chryso (Chrysotila sp.), G.mueller (G. muellerae), Holococco (holococcolithophores), Ophias (Ophiaster spp.), Papposph (Papposphaera sp. and Pappomonas spp.), Syracosph (Syracosphaera spp.), Wigwamm (Wigwamma antarctica), SAZ (Subantarctic Zone), PFZ (Polar Front Zone) and Chi (Chilean coastal zone).

(a) Number of taxa

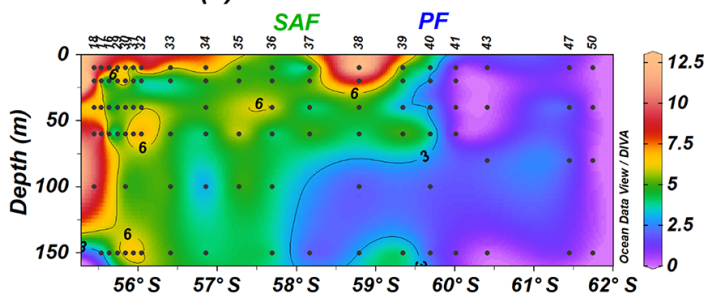

(d) Shannon index (H)

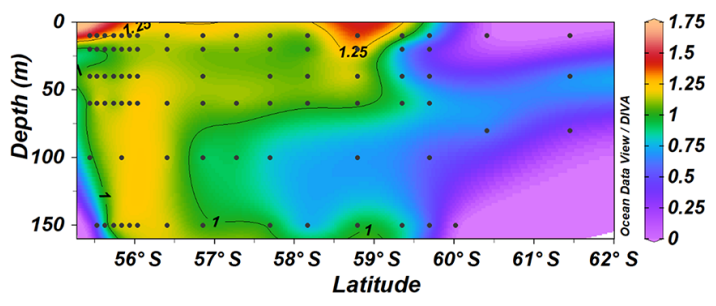

(b) Simpson index 1-D

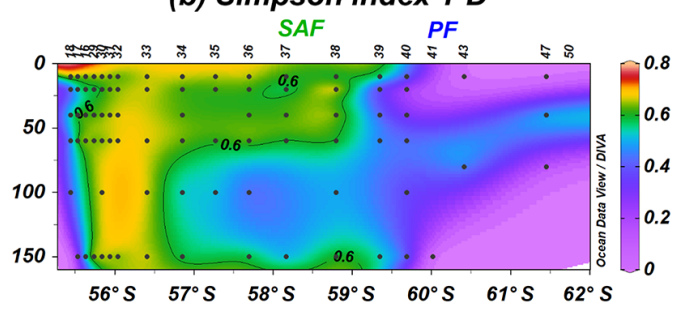

(e) Fisher's alpha

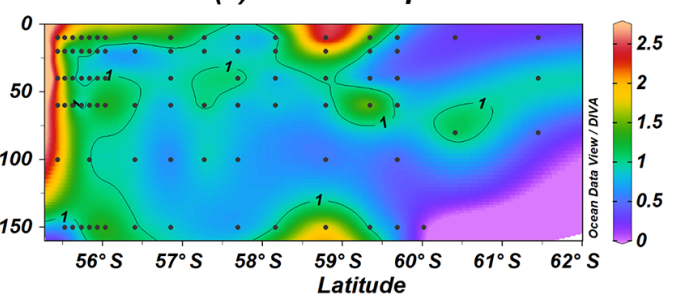

(c)

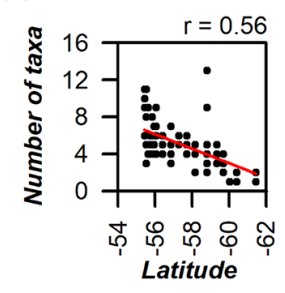

(f)

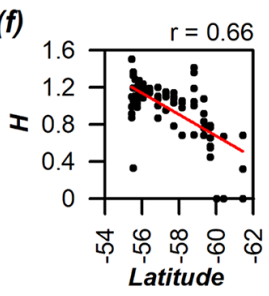

Figure 9. PS97 latitudinal transects showing coccolithophore diversity: (a) number of taxa, (b) Simpson index $1-D$, (c) number of taxa vs. latitude, (d) Shannon index $(H)$, (e) Fisher's alpha and (f) $H$ vs. latitude. The Subantarctic Front (SAF) and the Polar Front (PF), according to Orsi et al. (1995), are indicated. 
(a) E. huxleyi type A calcified-all (cells $L^{-1}$ )

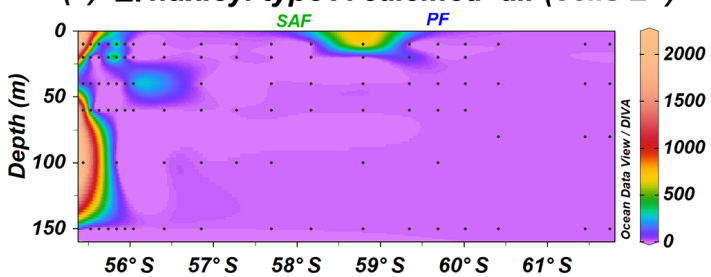

(c) E. huxleyi type $B / C$ calcified (cells $L^{-1}$ )

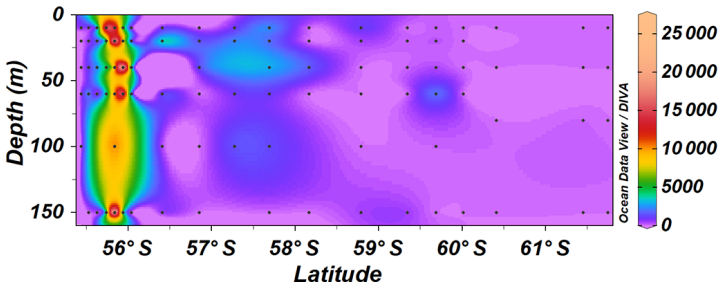

(b) E. huxleyi type B calcified (cells $L^{-1}$ )

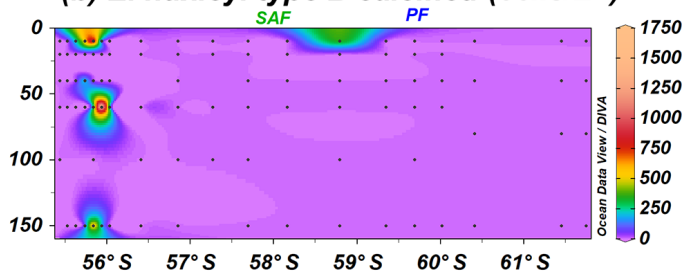

(d) E. huxleyi type $C$ calcified (cells $L^{-1}$ )

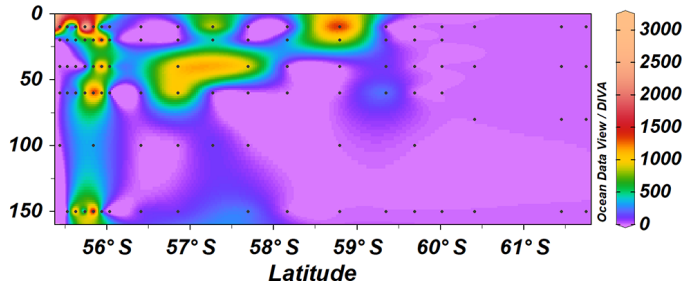

Figure 10. Location of the PS97 CTD stations studied, showing the number of coccospheres per litre of Emiliania huxleyi calcified and overcalcified (a) type A group, (b) type B, (c) type B/C, and (d) type C. The Subantarctic Front (SAF) and the Polar Front (PF), according to Orsi et al. (1995), are indicated.

diversity is related to the temperature gradient, as shown by the correlation between the Shannon index and SST $(r=0.8$; see Supplement). Contrary to Saavedra-Pellitero et al. (2014), the highest coccolithophore diversity values do not always occur at stations that showed the highest coccolithophore abundances (Figs. 3 and 9). A few studies off the shore of Chile (ca. 33 and $36^{\circ} \mathrm{S}$ ) and in the Drake Passage showed low coastal coccolithophore diversity increasing towards open ocean regions (Charalampopoulou et al., 2016; Menschel et al., 2016; von Dassow et al., 2018), which contrasts with the high number of taxa recorded in this work at uppermost $100 \mathrm{~m}$ of the water column at the Chilean margin (Fig. 9). Amongst different environmental factors, temperature could be one of the main variables favouring high coccolithophore diversity at the coastal stations.

The unexpected high diversity and number of taxa recorded at 10-20 $\mathrm{m}$ at station PS97/038-1 (previously labelled as an "outlier"), coincident with the relatively high density of coccospheres, do not seem to have been promoted by high SSTs but rather by an occasional variation in the nutrient availability. So far, there have been no nutrient measurements in situ available for this transect, but the interpolated values from the WOA13 austral summer suggest that nutrients are generally available this part of the SAZ, and shallow (10 and $20 \mathrm{~m}$ ) nitrate or phosphate concentrations (Fig. 12h and i) do not abruptly change at PS97/0381. Therefore this could be due to mesoscale eddies which could have advected nutrients (Frenger et al., 2018). We speculate that an increase in the fluorescence values (Fig. 2), reflecting higher chlorophyll- $a$ concentrations, could be attributed to a higher availability of nutrients, which could have favoured coccolithophores. The available fluorescence data (Fig. 2) seem to primarily reflect diatom concentration, south of the PF, followed by the non-coccolithophore haptophytes (Petasaria and Chrysochromulina spp.) in the SAZ and PFZ (up to $100 \mathrm{~m}$ water depth) superimposed to the coccolithophore distribution. Future quantitative analyses of extant diatoms and nutrients performed at the same stations and depths are envisaged and will be required for better understanding of the phytoplankton community interactions and ecological patterns across the Drake Passage.

\subsection{Community composition across the Drake Passage}

Based on the PCA (Fig. 8) it was possible to distinguish three main different oceanographic areas, characterized by different coccolithophore assemblages in the study area.

1. The Chilean margin. Coccolithophores dwell up to $150 \mathrm{~m}$ water depth in this zone (Fig. 3). Emiliania huxleyi type $\mathrm{A}$ is present in the stations closest to the Chilean coast (i.e. PS97/018-1 and PS97/017-1), which recorded the highest SST and lowest SSS in the study area. This morphotype of E. huxleyi has been also observed in low abundances north of the SAF in different Pacific and Australian Southern Ocean areas (e.g. Cubillos et al., 2007; Saavedra-Pellitero et al., 2014; Malinverno et al., 2015), although it was not observed by others authors (e.g. Gravalosa et al., 2008; Charalampopoulou et al., 2016), probably due to the high latitudes of those transects. Specimens of type A with different degrees of calcification were present, ranging from normal to overcalcified (Plate 1), the latter being more abundant. In the Northern Hemisphere, E. huxleyi type A dominates the coccolithophore assemblage in the North Atlantic and in Norwegian coastal waters (e.g. van Bleijswijk et al., 1991; Holligan et al., 1993) but not in the Southern Ocean (e.g. Cook et al., 2011; Hagino 


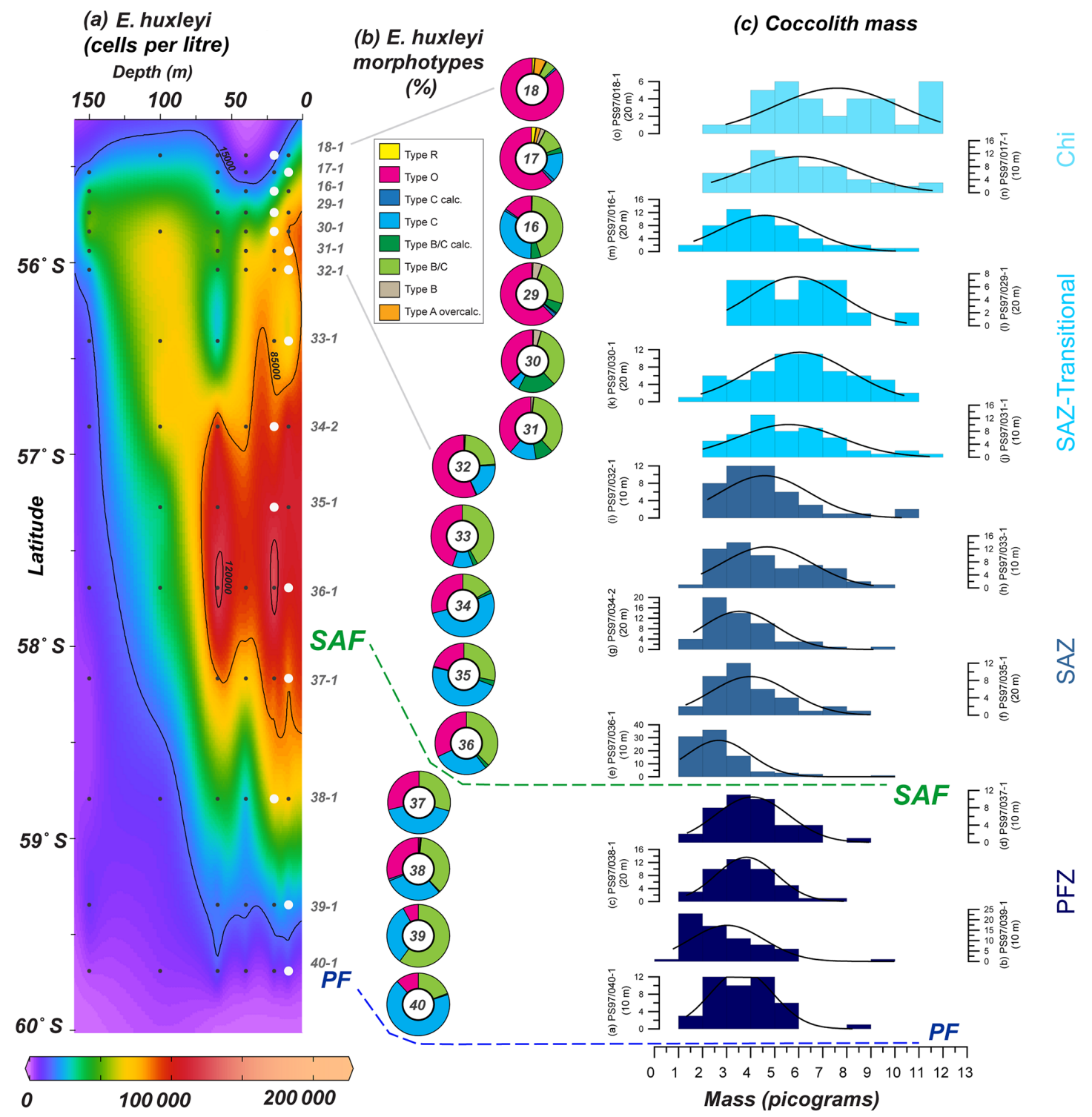

Figure 11. (a) Location of the PS97 CTD stations between 55.4 and $60^{\circ} \mathrm{S}$, showing the number of cells per litre of Emiliania huxleyi from 0 to $150 \mathrm{~m}$. (b) Relative abundance of E. huxleyi morphotypes (including the different degree of calcification observed in SEM) in a latitudinal transect (10-20 m; indicated with white dots in a); (c) coccolith mass histograms at those specific locations. Bin size in (c) is $1 \mathrm{pg}$, and normal distribution fitting line is shown. The station number, different zones (Chi - Chilean coastal zone; SAZ-Transitional - from Chi to open ocean; SAZ - Subantarctic Zone; PFZ - Polar Front Zone) and the main oceanographic fronts (Subantarctic Front - SAF - and Polar Front - PF), according to Orsi et al. (1995), are indicated.

et al., 2011). Emiliania huxleyi type R was observed for the first time in the Drake Passage, although it has been previously observed off of New Zealand (Langer et al., 2009; Iglesias-Rodriguez et al., 2017) and in the eastern South Pacific (Beaufort et al., 2008; Beaufort et al., 2011; von Dassow et al., 2018).

Other minor taxa present in the Chilean margin are Calcidiscus s.l. Ophiaster spp. and G. muellerae. The first has already been found by other authors in the SAZ (e.g. Saavedra-Pellitero et al., 2014; Malinverno et al.,
2015), but its patchy distribution north of the PF is in agreement with observations by Charalampopoulou et al. (2016). Ophiaster spp. shows uneven distribution in the SAZ and PFZ, but it is also present in the Chilean continental margin. Ophiaster spp. is recorded off the shore of Chile, with a low number living up to $100 \mathrm{~m}$ water depth, which contrasts with the high numbers observed in the SAZ off the shore of New Zealand that are always above $60 \mathrm{~m}$ (Saavedra-Pellitero et al., 2014). Occasional low numbers of extant G. muellerae 


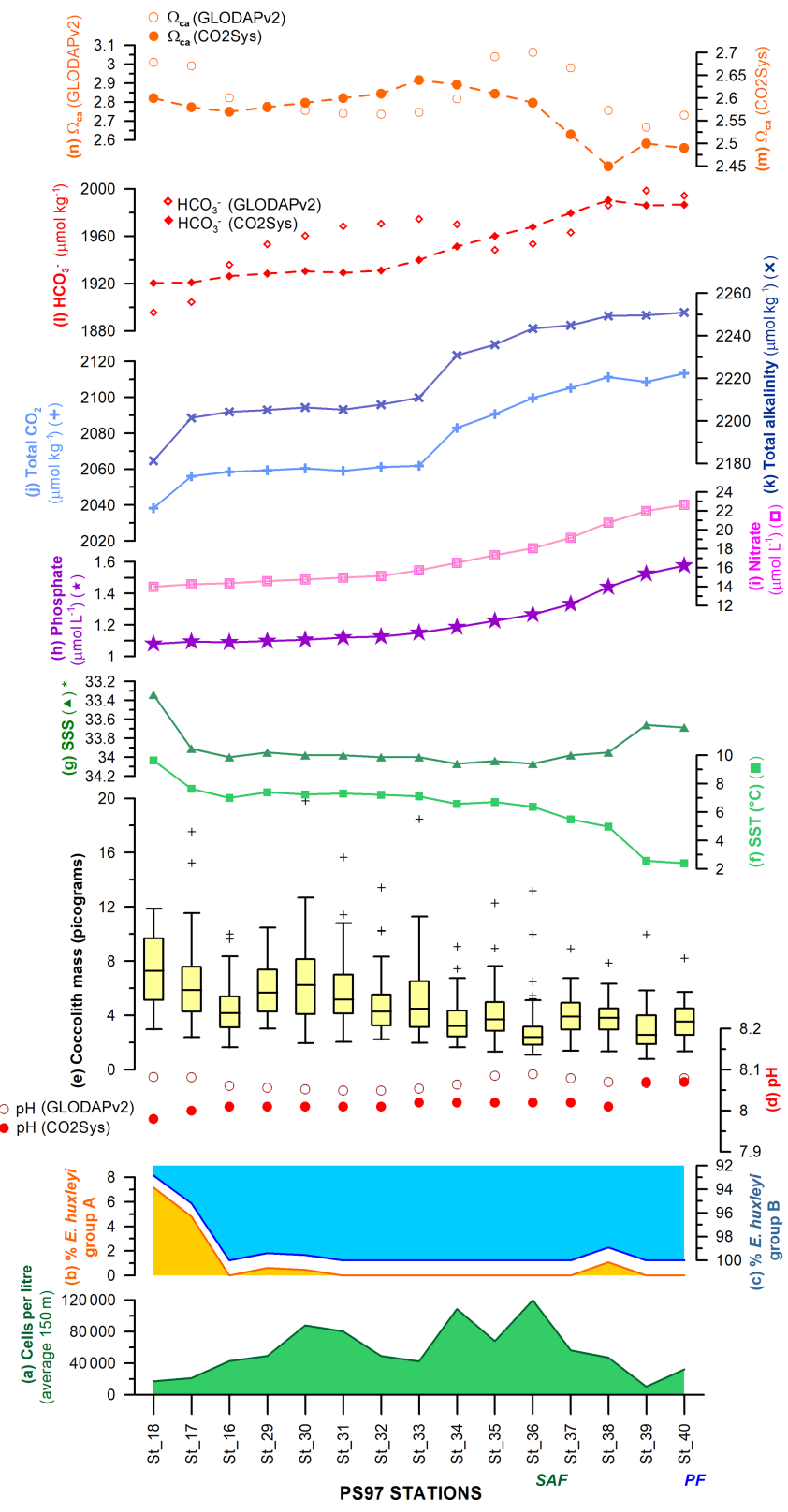

Figure 12. Latitudinal transect showing, on the left-hand side, (a) the uppermost $150 \mathrm{~m}$ average of cells per litre, relative abundance of E. huxleyi morphotypes belonging to (b) group A and (c) group $\mathrm{B}$, (d) $\mathrm{pH}$ calculated with different approaches (Pierrot et al., 2006; Key et al., 2015), (e) coccolith mass box plot (outliers are indicated with "+"), (f) sea-surface temperature (SST; $\left.{ }^{\circ} \mathrm{C}\right)$, and (g) salinity ( ${ }^{*}$ note the inverted scale) measured in situ (Lamy, 2016). Interpolated (h) phosphate $\left(\mu \mathrm{mol} \mathrm{L} \mathrm{L}^{-1}\right)$ and (i) nitrate contents ( $\mu \mathrm{mol} \mathrm{L}{ }^{-1}$; Garcia et al., 2014), (j) total alkalinity $\left(\mu \mathrm{mol} \mathrm{kg}{ }^{-1}\right)$ and $(\mathbf{k})$ total $\mathrm{CO}_{2}\left(\mu \mathrm{mol} \mathrm{kg}{ }^{-1}\right.$; Goyet et al., 2000$)$, (l) bicarbonate ion $\left(\mathrm{HCO}_{3}^{-}, \mu \mathrm{mol} \mathrm{kg}{ }^{-1}\right)$, and (m) calcite saturation state $\left(\Omega_{\mathrm{Ca}}\right)$ calculated with different approaches (Pierrot et al., 2006; Key et al., 2015). The Subantarctic Front (SAF) and Polar Front (PF), according to Orsi et al. (1995), are indicated. have also been observed in the Southern Ocean by Saavedra-Pellitero et al. (2014) and Findlay and Giraudeau (2000).

2. The SAZ. This oceanographic zone is bounded in the south by the SAF. Salinity values are relatively constant at about 34 practical salinity units (psu), but SST gradually decreases, down to ca. $6^{\circ} \mathrm{C}$, while the nitrate and phosphate contents progressively increase (Figs. 2 and 12). The SAZ is characterized by the dominance of $E$. huxleyi types $\mathrm{C}, \mathrm{B} / \mathrm{C}, \mathrm{O}$ and $\mathrm{B}$. The maximum coccolithophore depth habitat progressively decreases southwards from $150 \mathrm{~m}$ in the transitional zone south of the Chilean margin to $100 \mathrm{~m}$ in the open ocean (Fig. 3). The shift in occurrence from the type A group to the type B group has been recorded by some authors at the Subtropical Front (STF) in the Australian sector (e.g. Hiramatsu and De Deckker, 1996; Findlay and Giraudeau, 2000; Malinverno et al., 2015). Emiliania huxleyi type B appears in very low abundance, in agreement with Saavedra-Pellitero et al. (2014), restricted to a transitional narrow deep band $(0-150 \mathrm{~m})$ between the Chilean coastal margin and more open conditions of the SAZ. It has been observed also north of the STF in the Indian Southern Ocean (Patil et al., 2013). This morphotype was otherwise only found in the Northern Hemisphere (Cook et al., 2011).

Emiliania huxleyi type $\mathrm{O}$ was established by Hagino et al. (2011), who observed this morphotype extensively distributed in the Southern Ocean. However, so far only Malinverno et al. (2015) and this study described E. huxleyi type $\mathrm{O}$. This would mean that the reported geographic distributions of types $\mathrm{B} / \mathrm{C}$ and $\mathrm{C}$ might be biased by inclusion of type $\mathrm{O}$ (Hagino et al., 2011). Emiliania huxleyi type O (including the opened and lamella forms) is abundant in the SAZ, which is in agreement with Malinverno et al. (2015). Emiliania huxleyi type $\mathrm{B} / \mathrm{C}$ and $\mathrm{C}$ (see Table 1) are the dominant taxa in the SAZ of the Southern Ocean (e.g. Findlay and Giraudeau, 2000; Cubillos et al., 2007; Gravalosa et al., 2008; Mohan et al., 2008; Saavedra-Pellitero et al., 2014; Saavedra-Pellitero and Baumann, 2015).

Among minor taxa, Syracosphaera spp., Calcidiscus s.1., A. quattrospina and holococcolithophores are found in the SAZ, in agreement with the assemblage observed by Charalampopoulou et al. (2016) north of the PF. Four species belonging to the genus Syracosphaera (plus $S$. strigilis holococcolith phase) are recorded in the study area, as previously observed (Gravalosa et al., 2008; Charalampopoulou et al., 2016). Acanthoica quattrospina, a species tolerant to low salinity (Supraha et al., 2014), is present in southern high latitudes (Eynaud et al., 1999; Findlay and Giraudeau, 2000; Malinverno et al., 2015) but has not been recorded in other polar transects (e.g. Mohan et al., 2008). 
3. The PFZ. This oceanographic zone is bounded by the SAF and the PF. Salinity and SST gradually decrease with respect to the SAZ, and nutrient contents continue to progressively increase poleward (Figs. 2 and 12). The maximum coccolithophore depth habitat in this zone is restricted to $60 \mathrm{~m}$. Emiliania huxleyi types $\mathrm{B} / \mathrm{C}$ and $\mathrm{C}$ dominate the PFZ and reach relatively high numbers north of the PF, although E. huxleyi type $\mathrm{O}$ is still present in low abundance (Fig. 11), as also observed by Malinverno et al. (2015). The high coccolithophore numbers observed in the SAZ and at the shallowest depths of the PFZ are part of the Great Calcite Belt, a region of high surface reflectance in the Southern Ocean, due to the increased seasonal concentrations of coccolithophore and particulate inorganic carbon (Balch et al., 2011, 2016). We suggest that the uneven distribution of some of the coccolithophore taxa is driven by the physical processes of the ACC; i.e. it is primarily linked to the positions of frontal boundaries but also affected by the dynamics of mesoscale eddies, as mentioned by Holligan et al. (2010).

Minor taxa present in the PFZ, and broadly north of the PF, include species of the family Papposphaeraceae (i.e. Papposphaera sp., Pappomonas spp. and W. Antarctica). They have small-sized and lightly calcified coccoliths, which makes them easily overlooked even under SEM. Specimens from the genera Papposphaera and Pappomonas have been observed at polar waters in the Northern Hemisphere (Thomsen, 1981; Samtleben and Schröder, 1992; Charalampopoulou et al., 2011; Thomsen and Østergaard, 2014) and also in the Southern Ocean (e.g. Gravalosa et al., 2008; Saavedra-Pellitero et al., 2014; Charalampopoulou et al., 2016). Apart from the fact that the lightly calcified polar coccolithophores are non-photosynthetic heterotrophs, which gives them a strong competitive advantage to dwell in the darkness for months every year, very little is known about them (Thomsen and Østergaard, 2013). However, because they are weakly calcified, they will be one of the first polar taxa to be threatened by ocean acidification (Thomsen and Østergaard, 2013).

\subsection{Emiliania huxleyi mass variations across the Drake Passage}

In this study, the coccolith mass of E. huxleyi was measured across the Drake Passage up to the PF at depths ranging between 10 and $20 \mathrm{~m}$ water depth. The general southwards decreasing trend in E. huxleyi mass (Fig. 11) is in agreement with trends observed by Charalampopoulou et al. (2016) across the Southern Ocean (Fig. 13). Differences in the estimated masses can be attributed to the distinct taxonomical considerations, to the methodologies used in both studies and mainly to the different oceanographic conditions during the sampling periods (2009 and 2016). The mean coccolith mass is related to strong latitudinal gradients in temperature $(r=$ 0.75), also observed by Charalampopoulou et al. (2016), total alkalinity $(r=-0.89)$, total $\mathrm{CO}_{2}(r=-0.86), \mathrm{HCO}_{3}^{-}$ ( $r=-0.81$ or -0.68 depending on the method used to calculate it) in agreement with Beaufort et al. (2011) and nutrient content (nitrate: $r=-0.75$; phosphate: -0.71 ) noted by Charalampopoulou et al. (2016; Table 4 and Fig. 12). In contrast, the coccolith mass relationship to salinity, fluorescence, silicate content, carbonate ion and calcite saturation is not significant (Table 4). Still it could be argued that the poleward decrease in coccolith mass roughly coincides with a reduction in $\Omega_{\mathrm{Ca}}$ (Fig. 12) and $\mathrm{CO}_{3}^{2-}$ (Table 4), in agreement with different studies that found depressed coccolith calcification at low $\Omega_{\mathrm{Ca}}$ and $\mathrm{CO}_{3}^{2-}$ values (e.g. Riebesell et al., 2000; Beaufort et al., 2011). Although the $\mathrm{pH}$ variation is rather reduced, the anticorrelation between coccolith mass and $\mathrm{pH}$ becomes significant $(r=-0.7)$ depending on the method used (Table 4 and Fig. 12), in agreement with the Biogeochemistry and Optics South Pacific experiment (BIOSOPE) data from Beaufort et al. (2011; $r=-0.52)$. The negative correlation of the present data contrasts with the global and well-established relationship between coccolith mass and $\mathrm{pH}$ $(r=0.75$; Beaufort et al., 2011). However, the relationship between coccolith mass and the carbonate chemistry parameters should be considered carefully. $T_{\mathrm{ALK}}, T_{\mathrm{CO}_{2}}, \Omega_{\mathrm{Ca}}, \mathrm{pH}$ and $\mathrm{HCO}_{3}^{-}$have been calculated from the GLODAPv2 database (in which the majority of the data points are scattered and samples were measured just in August 2005 and in February 2009; Key et al., 2015) or from the global alkalinity and total dissolved carbon collection (Goyet et al., 2000) which shows an austral summer average using the CO2Sys.xls program (Pierrot et al., 2006).

The observed decreasing trend of the coccolith mass can be linked to the latitudinal succession from the type A group to the type B group (Fig. 12b), in agreement with other authors who observed a latitudinal trend from $E$. huxleyi more calcified to weakly calcified morphotypes (e.g. Cubillos et al., 2007; Mohan et al., 2008). In the Chilean margin, the highest coccolith masses recorded are related to the presence of E. huxleyi type A (including normal, calcified and overcalcified specimens) and type R (Fig. 11), observed also by other authors at lower latitudes off the shore of Chile (Beaufort et al., 2008, 2011; von Dassow et al., 2018). Although it is uncommon, heavily calcified E. huxleyi morphotypes have been recorded in reduced $\mathrm{pH}$ and $\Omega_{\mathrm{Ca}}$ conditions in other parts of the globe (e.g. Smith et al., 2012; Triantaphyllou et al., 2018). The presence of calcified specimens of $E$. huxleyi type $\mathrm{B} / \mathrm{C}$, and to a lesser extent of type $\mathrm{C}$, in the transitional zone from the Chilean margin to the open ocean reflects an increase in the coccolith masses (Figs. 10 and 11). In contrast, a higher relative abundance of $E$. huxleyi type $\mathrm{C}$ corresponds to smaller coccolith masses in the SAZ. Striking are the relatively low coccolith mass values in the open ocean of the SAZ that coincide with maxima in the density of coccolithophores (Fig. 12). 
Table 4. Correlation matrix between mean and median coccolith values and the environmental variables. Significant Pearson correlation coefficients are indicated in bold $(p<0.05)$. Measurements in situ and calculated values are indicated.

\begin{tabular}{|c|c|c|c|}
\hline \multicolumn{2}{|c|}{$\begin{array}{l}\text { Environmental } \\
\text { variables }\end{array}$} & $\begin{array}{r}\text { Mean coccolith } \\
\text { mass (pg) }\end{array}$ & $\begin{array}{r}\text { Median coccolith } \\
\text { mass (pg) }\end{array}$ \\
\hline \multirow{3}{*}{ 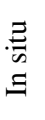 } & Temperature & 0.75 & 0.71 \\
\hline & Salinity & -0.35 & -0.37 \\
\hline & Fluorescence & 0.10 & 0.13 \\
\hline \multirow{13}{*}{$\frac{\frac{\vec{d}}{\bar{J}}}{\frac{\vec{J}}{\tilde{J}}}$} & Phosphate & -0.71 & -0.66 \\
\hline & Nitrate & -0.75 & -0.70 \\
\hline & Silicate & -0.35 & -0.31 \\
\hline & Total $\mathrm{CO}_{2}$ & -0.82 & -0.77 \\
\hline & Total Alkalinity & -0.85 & -0.81 \\
\hline & $\mathrm{HCO}_{3}^{-}$GlODAPv2 & -0.68 & -0.66 \\
\hline & $\mathrm{HCO}_{3}^{-} \mathrm{CO} 2 \mathrm{Sys}$ & -0.81 & -0.75 \\
\hline & pH GLODAPv2 & -0.25 & -0.22 \\
\hline & $\mathrm{pH}$ CO2Sys & -0.70 & -0.69 \\
\hline & $\mathrm{CO}_{3}^{2-}$ GLODAPv2 & 0.09 & 0.08 \\
\hline & $\mathrm{CO}_{3}^{2-} \mathrm{CO} 2 \mathrm{Sys}$ & 0.40 & 0.32 \\
\hline & $\Omega_{\mathrm{ca}}$ GLODAPv2 & 0.10 & 0.10 \\
\hline & $\Omega_{\mathrm{ca}} \mathrm{CO} 2 \mathrm{Sys}$ & 0.39 & 0.31 \\
\hline
\end{tabular}

The dataset presented here constitutes an important contribution to the coccolithophore ecology sparsely studied at high latitudes. This work is also relevant for future climate and ocean model simulations in the context of global warming and ocean acidification threatening calcifying plankton. Taking into account the existing relationships between the physico-chemical parameters and the coccolithophore components and changes in the composition and calcification modes of E. huxleyi morphotypes are expected to occur in the Drake Passage with the ongoing climate change. However, our study does not provide enough evidence to infer how coccolithophores will cope with a future changing ocean. We speculate that future sea-surface warming and stratification (Boyd et al., 2008), concomitant with a southward migration of the Antarctic Circumpolar Current fronts, will lead to a increase in the numbers of E. huxleyi at higher latitudes and to a potential higher calcification poleward, in agreement with the model from Krumhardt et al. (2017). At the same time, $\mathrm{pH}, \mathrm{CO}_{3}^{2-}$ and $\Omega_{\mathrm{Ca}}$ are predicted to decrease (e.g. Hauri et al., 2015), which will also affect coccolithophores. Based on our limited data, conflicting conclusions can be drawn from the carbonate parameters. We could hypothesize that E. huxleyi will calcify more in a future Southern Ocean scenario at a lower $\mathrm{pH}$, consistent with a few culture experiments (e.g. Iglesias-Rodriguez et al., 2008), but also that this species will reduce its calcification rate at lower $\mathrm{CO}_{3}^{2-}$ and $\Omega_{\mathrm{Ca}}$ and higher $\mathrm{HCO}_{3}^{-}$, in agreement with the negative effects of ocean acidification suggested by several authors (e.g. Riebesell et al., 2000). Bearing in mind that culture experiments in different strains of $E$. huxleyi have already shown

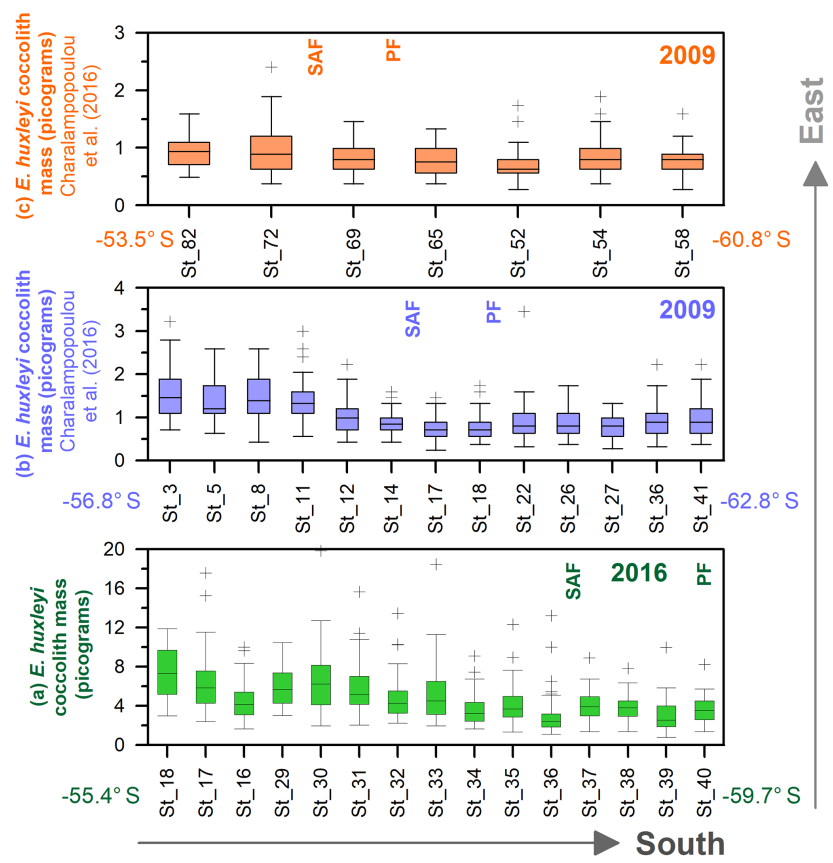

Figure 13. Drake Passage latitudinal transects from east to west, showing box plot coccolith mass estimates (in pg): (a) this study, (b) transect at around $68^{\circ} \mathrm{W}$ from Charalampopoulou et al. (2016), and (c) transect at around $55-58^{\circ} \mathrm{W}$ from Charalampopoulou et al. (2016). Note that $(\mathbf{b}, \mathbf{c})$ have been calculated from Charalampopoulou et al. (2016). Outliers have been indicated with "+", and numbers on the $x$ axes refer to the original station numbers. The approximate location of the Subantarctic Front (SAF) and Polar Front $(\mathrm{PF})$ are shown as well as the year of the sampling.

different responses to changing carbonate chemistry (Langer et al., 2009), it seems necessary to consider also the degree of adaptive potential of coccolithophores in future studies to predict their upcoming performance in the polar realm.

\section{Conclusions}

This study documents the latitudinal and the depth variability in the coccolithophore assemblage composition and calcification of Emiliania huxleyi, the dominant species, across the Drake Passage, driven by physical, chemical and biological parameters in the surface ocean. Coccolithophore abundance, diversity and maximum depth habitat decrease southwards, portraying the oceanographic fronts as ecological boundaries. Marked shifts in the coccolithophore numbers, community composition and diversity occur at the Subantarctic Front (SAF) and Polar Front (PF). Three main different oceanographic areas are characterized based on the coccolithophore composition:

1. The Chilean margin. Emiliania huxleyi type A (normal and overcalcified) and type $\mathrm{R}$ are present in the stations closest to the Chilean coast, which record the highest 
SST and lowest SSS in the study area. Rare taxa present off the shore of Chile are Calcidiscus s.l., Ophiaster spp. and Gephyrocapsa muellerae.

2. The Subantarctic Zone (SAZ). This zone is bounded by the SAF in the south. Salinity values are relatively constant, and SST gradually decreases while nutrient content increases. The SAZ is characterized by the dominance of $E$. huxleyi types $\mathrm{C}, \mathrm{B} / \mathrm{C}, \mathrm{O}$ and $\mathrm{B}$. Emiliania huxleyi reaches maximum values of $212.5 \times$ $10^{3}$ cells $\mathrm{L}^{-1}$ north in the SAZ. Minor taxa include Syracosphaera spp. (including holococcolithophores from this genus), Calcidiscus s.l. and Acanthoica quattrospina.

3. The Polar Front Zone (PFZ). It is bounded by the SAF in the north and the PF in the south. Salinity and SST progressively decreases with respect to the SAZ, and nutrient contents continue to increase poleward. Emiliania huxleyi types $\mathrm{B} / \mathrm{C}$ and $\mathrm{C}$ dominate the PFZ and reach relatively high numbers north of the $\mathrm{PF}$, although E. huxleyi type $\mathrm{O}$ is still present. Minor taxa present in the PFZ, and broadly north of the PF, include species of the family Papposphaeraceae (i.e. Papposphaera sp., Pappomonas spp. and Wigwamma antarctica). Specimens of $E$. huxleyi and W. antarctica are sporadically recorded south of the $\mathrm{PF}$, with num-

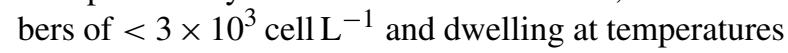
$<2{ }^{\circ} \mathrm{C}$.

The general decreasing trend in E. huxleyi coccolith mass can be linked to the latitudinal succession from the type A group (in the Chilean margin) to the type B group (in the PFZ). Coccolith mass and coccolithophore diversity are related to the strong latitudinal gradient in temperature. Coccolith mass also shows anticorrelation to total alkalinity, total $\mathrm{CO}_{2}$, bicarbonate ion $\left(\mathrm{HCO}_{3}^{-}\right), \mathrm{pH}$ and nutrient content, which contrasts with the global and well-established positive relationship between coccolith mass and $\mathrm{pH}$ as well as total alkalinity. However, the relationship between coccolith mass and the carbonate chemistry parameters should be considered carefully, since in situ measurements are not available. The existing relationships between the physico-chemical parameters and the coccolithophore components in the Drake Passage suggest that assemblage composition and calcification modes of $E$. huxleyi will be strongly affected by the ongoing climate change.
Data availability. Data are available in the Pangaea data repository: https://doi.pangaea.de/10.1594/PANGAEA.901294 (Saavedra-Pellitero and Baumann, 2019).

Supplement. The supplement related to this article is available online at: https://doi.org/10.5194/bg-16-3679-2019-supplement.

Author contributions. MSP and KHB designed the research. HS took the samples during Expedition PS97. MSP and NMV prepared the samples. MSP identified and counted the coccolithophore specimens, with help from NMV and KHB. MAF provided the expertise to perform the light microscopy image analysis and JAF contributed with analytical tools. YM wrote the MATLAB script to estimate the oceanographic parameters at the CTD stations. MSP analysed data and performed calculations. FL contributed with oceanographic expertise. MSP wrote the paper with feedback from all the authors.

Competing interests. The authors declare that they have no conflict of interest.

Acknowledgements. The Alfred Wegener Institute Bremerhaven provided the plankton samples required for this study. R/V POLARSTERN officers and crew are thanked for their help during the PS97 Expedition. Marius Becker (University of Kiel) is acknowledged for his help with MATLAB ${ }^{\mathrm{TM}}$ as well as Jeremy Young (University College London) for his assistance with coccolithophore identification. Chloe Anderson (MARUM) and Diederik Liebrand (University of Bremen) are thanked for their comments on the paper, and José Ignacio (USAL) for his help in the lab. The authors are also grateful to two anonymous referees for their suggestions on a previous version of the paper.

Financial support. This research has been supported by the Deutsche Forschungsgemeinschaft (grant no. BA 1648/30-1) to Karl-Heinz Baumann, with funding for Mariem Saavedra-Pellitero.

The article processing charges for this open-access publication were covered by the University of Bremen.

Review statement. This paper was edited by Emilio Marañón and reviewed by two anonymous referees. 


\section{References}

Balch, W. M., Drapeau, D. T., Bowler, B. C., Lyczskowski, E., Booth, E. S., and Alley, D.: The contribution of coccolithophores to the optical and inorganic carbon budgets during the Southern Ocean Gas Exchange Experiment: New evidence in support of the "Great Calcite Belt" hypothesis, J. Geophys. Res.-Ocean., 116, C00F06, https://doi.org/10.1029/2011JC006941, 2011.

Balch, W. M., Bates, N. R., Lam, P. J., Twining, B. S., Rosengard, S. Z., Bowler, B. C., Drapeau, D. T., Garley, R., Lubelczyk, L. C., Mitchell, C., and Rauschenberg, S.: Factors regulating the Great Calcite Belt in the Southern Ocean and its biogeochemical significance, Global Biogeochem. Cy., 30, 1124-1144, https://doi.org/10.1002/2016gb005414, 2016.

Beaufort, L., Couapel, M., Buchet, N., Claustre, H., and Goyet, C.: Calcite production by coccolithophores in the south east Pacific Ocean, Biogeosciences, 5, 1101-1117, https://doi.org/10.5194/bg-5-1101-2008, 2008.

Beaufort, L., Probert, I., de Garidel-Thoron, T., Bendif, E. M., RuizPino, D., Metzl, N., Goyet, C., Buchet, N., Coupel, P., Grelaud, M., Rost, B., Rickaby, R. E. M., and de Vargas, C.: Sensitivity of coccolithophores to carbonate chemistry and ocean acidification, Nature, 476, 80-83, https://doi.org/10.1038/nature10295, 2011.

Blanco-Ameijeiras, S., Lebrato, M., Stoll, H. M., IglesiasRodriguez, D., Müller, M. N., Méndez-Vicente, A., and Oschlies, A.: Phenotypic Variability in the Coccolithophore Emiliania huxleyi, PloS one, 11, e0157697, https://doi.org/10.1371/journal.pone.0157697, 2016.

Boyd, P. W., Doney, S. C., Strzepek, R., Dusenberry, J., Lindsay, K., and Fung, I.: Climate-mediated changes to mixed-layer properties in the Southern Ocean: assessing the phytoplankton response, Biogeosciences, 5, 847-864, https://doi.org/10.5194/bg5-847-2008, 2008.

Cabré, A., Marinov, I., and Leung, S.: Consistent global responses of marine ecosystems to future climate change across the IPCC AR5 earth system models, Clim. Dynam., 45, 1253-1280, https://doi.org/10.1007/s00382-014-2374-3, 2015.

Cárdenas, P., Lange, C. B., Vernet, M., Esper, O., Srain, B., Vorrath, M.-E., Ehrhardt, S., Müller, J., Kuhn, G., Arz, H. W., LembkeJene, L., and Lamy, F.: Biogeochemical proxies and diatoms in surface sediments across the Drake Passage reflect oceanic domains and frontal systems in the region, Prog. Oceanogr., 174, 72-88, https://doi.org/10.1016/j.pocean.2018.10.004, 2018.

Charalampopoulou, A., Poulton, A. J., Tyrrell, T., and Lucas, M. I.: Irradiance and $\mathrm{pH}$ affect coccolithophore community composition on a transect between the North Sea and the Arctic Ocean, Mar. Ecol.-Prog. Ser., 431, 25-43, https://doi.org/10.3354/meps09140, 2011.

Charalampopoulou, A., Poulton, A. J., Bakker, D. C. E., Lucas, M. I., Stinchcombe, M. C., and Tyrrell, T.: Environmental drivers of coccolithophore abundance and calcification across Drake Passage (Southern Ocean), Biogeosciences, 13, 59175935, https://doi.org/10.5194/bg-13-5917-2016, 2016.

Comiso, J. C.: Large-scale Characteristics and Variability of the Global Sea Ice Cover, in: Sea Ice, Blackwell Science Ltd., Oxford, 2003.

Cook, S. S., Whittock, L., Wright, S. W., and Hallegraeff, G. M.: Photosynthetic pigment and genetic differences between two Southern Ocean morphotypes of Emiliania huxleyi (Hapto- phyta), J. Phycol., 47, 615-626, https://doi.org/10.1111/j.15298817.2011.00992.x, 2011.

Cubillos, J. C., Wright, S. W., Nash, G., de Salas, M. F., Griffiths, B., Tilbrook, B., Poisson, A., and Hallegraeff, G. M.: Calcification morphotypes of the coccolithophorid Emiliania huxleyi in the Southern Ocean: changes in 2001 to 2006 compared to historical data, Mar. Ecol.-Prog. Ser., 348, 47-54, https://doi.org/10.3354/meps07058, 2007.

Davis, J. C.: Statistics and Data Analysis in Geology, John Wiley \& Sons Inc., New York, 1986.

Dylmer, C. V., Giraudeau, J., Hanquiez, V., and Husum, K.: The coccolithophores Emiliania huxleyi and Coccolithus pelagicus: Extant populations from the NorwegianIceland Sea and Fram Strait, Deep-Sea Res. Pt. I, 98, 1-9, https://doi.org/10.1016/j.dsr.2014.11.012, 2015.

Eynaud, F., Giraudeau, J., Pichon, J. J., and Pudsey, C. J.: Seasurface distribution of coccolithophores, diatoms, silicoflagellates and dinoflagellates in the South Atlantic Ocean during the late austral summer 1995, Deep-Sea Res. Pt. I, 46, 451-482, https://doi.org/10.1016/S0967-0637(98)00079-X, 1999.

Fabry, V. J., Seibel, B. A., Feely, R. A., and Orr, J. C.: Impacts of ocean acidification on marine fauna and ecosystem processes, ICES J. Mar. Sci., 65, 414-432, https://doi.org/10.1093/icesjms/fsn048, 2008.

Fabry, V. J., McClintock, J. B., Mathis, J. T., and Grebmeier, J. M.: Ocean acidification at high latitudes: The bellwether, Oceanography, 22, 160-171, https://doi.org/10.5670/oceanog.2009.105, 2009.

Findlay, C. S. and Giraudeau, J.: Extant calcareous nannoplankton in the Australian Sector of the Southern Ocean (austral summers 1994 and 1995), Mar. Micropaleontol., 40, 417-439, https://doi.org/10.1016/S0377-8398(00)00046-3, 2000.

Findlay, H. S., Calosi, P., and Crawfurd, K.: Determinants of the PIC: POC response in the coccolithophore Emiliania huxleyi under future ocean acidification scenarios, Limnol. Oceanogr., 56, 1168-1178, https://doi.org/10.4319/lo.2011.56.3.1168, 2011.

Franks, P. J. S.: Sink or swim: accumulation of biomass at fronts, Mar. Ecol.-Prog. Ser., 82, 1-12, https://doi.org/10.3354/meps082001, 1992.

Freeman, N. M. and Lovenduski, N. S.: Decreased calcification in the Southern Ocean over the satellite record, Geophys. Res. Lett., 42, 1834-1840, https://doi.org/10.1002/2014g1062769, 2015.

Frenger, I., Münnich, M., and Gruber, N.: Imprint of Southern Ocean mesoscale eddies on chlorophyll, Biogeosciences, 15, 4781-4798, https://doi.org/10.5194/bg-15-4781-2018, 2018.

Fuertes, M.-Á., Flores, J.-A., and Sierro, F. J.: The use of circularly polarized light for biometry, identification and estimation of mass of coccoliths, Mar. Micropaleontol., 113, 44-55, https://doi.org/10.1016/j.marmicro.2014.08.007, 2014.

Garcia, H. E., Locarnini, R. A., Boyer, T. P., Antonov, J. I., Baranova, O. K., Zweng, M. M., Reagan, J. R., and Johnson, D. R.: World Ocean Atlas 2013, in: NOAA Atlas NESDIS 76, edited by: Levitus, S. E., A. Mishonov Technical Edn., U.S. Government Printing Office, Washington, D.C., 25 pp., 2014.

Gattuso, J.-P., Bijma, J., Gehlen, M., Riebesell, U., and Turley, C.: Ocean acidification: knowns, unknowns and perspectives, in: Ocean acidification, edited by: Gattuso, J.-P. and Hansson, L., Oxford University Press, Oxford, 291-311, 2011. 
Giraudeau, J., Hulot, V., Hanquiez, V., Devaux, L., Howa, H., and Garlan, T.: A survey of the summer coccolithophore community in the western Barents Sea, J. Marine Syst., 158, 93-105, https://doi.org/10.1016/j.jmarsys.2016.02.012, 2016.

Goyet, C., Healy, R., Ryan, J., and Kozyr, A.: Global Distribution of Total Inorganic Carbon and Total Alkalinity below the Deepest Winter Mixed Layer Depths. Carbon Dioxide Information Analysis Center, USA, https://doi.org/10.2172/760546, 2000.

Gravalosa, J. M., Flores, J.-A., Sierro, F. J., and Gersonde, R.: Sea surface distribution of coccolithophores in the eastern Pacific sector of the Southern Ocean (Bellingshausen and Amundsen Seas) during the late austral summer of 2001, Mar. Micropaleontol., 69, 16-25, https://doi.org/10.1016/j.marmicro.2007.11.006, 2008.

Hagino, K., Okada, H., and Matsuoka, H.: Coccolithophore assemblages and morphotypes of Emiliania huxleyi in the boundary zone between the cold Oyashio and warm Kuroshio currents off the coast of Japan, Mar. Micropaleontol., 55, 19-47, https://doi.org/10.1016/j.marmicro.2005.02.002, 2005.

Hagino, K., Bendif, E. M., Young, J. R., Kogame, K., Probert, I., Takano, Y., Horiguchi, T., de Vargas, C., and Okada, H.: New evidence for morphological and genetic variation in the cosmopolitan coccolithophore Emiliania huxleyi (Prymnesiophyceae) from the COX1b-ATP4 genes, J. Phycol., 47, 11641176, https://doi.org/10.1111/j.1529-8817.2011.01053.x, 2011.

Hammer, Ø., Harper, D. A. T., and Ryan, P. D.: PAST: paleontological Statistics software package for education and data analysis, Paleontologia Electronica, 49, 9, 2001.

Harada, N., Sato, M., Oguri, K., Hagino, K., Okazaki, Y., Katsuki, K., Tsuji, Y., Shin, K.-H., Tadai, O., Saitoh, S.-I., Narita, H., Konno, S., Jordan, R. W., Shiraiwa, Y., and Grebmeier, J.: Enhancement of coccolithophorid blooms in the Bering Sea by recent environmental changes, Global Biogeochem. Cy., 26, GB2036, https://doi.org/10.1029/2011gb004177, 2012.

Harper, D. A. T.: Numerical Palaeobiology, John Wiley \& Sons, Chichester, 1999.

Hauri, C., Friedrich, T., and Timmermann, A.: Abrupt onset and prolongation of aragonite undersaturation events in the Southern Ocean, Nat. Clim. Change, 6, 172, https://doi.org/10.1038/nclimate2844, 2015.

Hinz, D. J., Poulton, A. J., Nielsdóttir, M. C., Steigenberger, S., Korb, R. E., Achterberg, E. P., and Bibby, T. S.: Comparative seasonal biogeography of mineralising nannoplankton in the Scotia Sea: Emiliania huxleyi, Fragilariopsis spp. and Tetraparma pelagica, Deep-Sea Res. Pt. II, 59-60, 57-66, https://doi.org/10.1016/j.dsr2.2011.09.002, 2012.

Hiramatsu, C. and De Deckker, P.: Distribution of calcareous nannoplankton near the Subtropical Convergence, south of Tasmania, Australia, Mar. Freshwater Res., 47, 707-713, https://doi.org/10.1071/MF9960707, 1996.

Holligan, P. M., Fernández, E., Aiken, J., Balch, W. M., Boyd, P., Burkill, P. H., Finch, M., Groom, S. B., Malin, G., Muller, K., Purdie, D. A., Robinson, C., Trees, C. C., Turner, S. M., and van der Wal, P.: A biogeochemical study of the coccolithophore, Emiliania huxleyi, in the North Atlantic, Global Biogeochem. Cy., 7, 879-900, https://doi.org/10.1029/93gb01731, 1993.

Holligan, P. M., Charalampopoulou, A., and Hutson, R.: Seasonal distributions of the coccolithophore, Emiliania huxleyi, and of particulate inorganic carbon in surface wa- ters of the Scotia Sea, J. Marine Syst., 82, 195-205, https://doi.org/10.1016/j.jmarsys.2010.05.007, 2010.

Iglesias-Rodriguez, M. D., Halloran, P. R., Rickaby, R. E. M., Hall, I. R., Colmenero-Hidalgo, E., Gittins, J. R., Green, D. R. H., Tyrrell, T., Gibbs, S. J., von Dassow, P., Rehm, E., Armbrust, E. V., and Boessenkool, K. P.: Phytoplankton calcification in a high- $\mathrm{CO}_{2}$ world, Science, 320, 336-340, https://doi.org/10.1126/science.1154122, 2008.

Iglesias-Rodriguez, M. D., Jones, B. M., Blanco-Ameijeiras, S., Greaves, M., Huete-Ortega, M., and Lebrato, M.: Physiological responses of coccolithophores to abrupt exposure of naturally low $\mathrm{pH}$ deep seawater, PLOS ONE, 12, e0181713, https://doi.org/10.1371/journal.pone.0181713, 2017.

Jordan, R. W., Cros, L., and Young, J. R.: A revised classification scheme for living haptophytes, Micropaleontology, 50, 55-79, https://doi.org/10.2113/50.Suppl_1.55, 2004.

Key, R. M., Olsen, A., van Heuven, S., Lauvset, S. K., Velo, A., Lin, X., Schirnick, C., Kozyr, A., Tanhua, T., Hoppema, M., Jutterström, S., Steinfeldt, R., Jeansson, E., Ishii, M., Perez, F. F., and Suzuki, T.: Global Data Analysis Project (GLODAP), Version 2, U.S. Department of Energy, Tennessee, 2015.

Krumhardt, K. M., Lovenduski, N. S., Freeman, N. M., and Bates, N. R.: Apparent increase in coccolithophore abundance in the subtropical North Atlantic from 1990 to 2014, Biogeosciences, 13, 1163-1177, https://doi.org/10.5194/bg-13-1163-2016, 2016.

Krumhardt, K. M., Lovenduski, N. S., Iglesias-Rodriguez, M. D., and Kleypas, J. A.: Coccolithophore growth and calcification in a changing ocean, Prog. Oceanogr., 159, 276-295, https://doi.org/10.1016/j.pocean.2017.10.007, 2017.

Krumhardt, K. M., Lovenduski, N. S., Long, M. C., Levy, M., Lindsay, K., Moore, J. K., and Nissen, C.: Coccolithophore growth and calcification in an acidified ocean: Insights from Community Earth System Model simulations, J. Adv. Model. Earth Sy., 11, 1418-1437, https://doi.org/10.1029/2018ms001483, 2019.

Lamy, F.: The Expedition PS97 of the Research Vessel POLARSTERN to the Drake Passage in 2016, edited by: Lamy, F., Berichte zur Polar- und Meeresforschung, Reports on Polar and Marine Research, 167 pp., https://doi.org/10.2312/BzPM_0701_2016, 2016.

Langer, G., Nehrke, G., Probert, I., Ly, J., and Ziveri, P.: Strain-specific responses of Emiliania huxleyi to changing seawater carbonate chemistry, Biogeosciences, 6, 2637-2646, https://doi.org/10.5194/bg-6-2637-2009, 2009.

Laubscher, R. K., Perissinotto, R., and McQuaid, C. D.: Phytoplankton production and biomass at frontal zones in the Atlantic sector of the Southern Ocean, Polar Biol., 13, 471-481, https://doi.org/10.1007/BF00233138, 1993.

Locarnini, R. A., Mishonov, A. V., Antonov, J. I., Boyer, T. P., Garcia, H. E., Baranova, O. K., Zweng, M. M., Paver, C. R., Reagan, J. R., Johnson, D. R., Hamilton, M., and Seidov, D.: World ocean atlas 2013, in: Volume 1: Temperature, NOAA Atlas NESDIS, Vol. 73, edited by: Levitus, S. A. E., Mishonov Technical Ed., NOAA, Silver Spring, Md, 40 pp., 2013.

Malinverno, E., Triantaphyllou, M. V., and Dimiza, M. D.: Coccolithophore assemblage distribution along a temperate to polar gradient in the West Pacific sector of the Southern Ocean (January 2005), Micropaleontology, 61, 489-506, 2015.

Malinverno, E., Maffioli, P., and Gariboldi, K.: Latitudinal distribution of extant fossilizable phytoplankton in the South- 
ern Ocean: Planktonic provinces, hydrographic fronts and palaeoecological perspectives, Mar. Micropaleontol., 123, 4158, https://doi.org/10.1016/j.marmicro.2016.01.001, 2016.

Malone, T., Azzaro, M., Bode, A., Brown, E., Duce, R., Kamykowski, D., Kang, S. H., Kedong, Y., Thorndyke, M., Wang, J., Park, C., Calumpong, H., and Eghtesadi, P.: Primary Production, Cycling of Nutrients, Surface Layer and Plankton, in: The First Global Integrated Marine Assessment: World Ocean Assessment I, edited by United Nations, Cambridge University Press, Cambridge, 119-148, 2017.

McIntyre, A. and Bé, A. W. H.: Modern coccolithophoridae of the Atlantic Ocean. Placoliths and Cyrtoliths, Deep-Sea Res., 14, 561-597, 1967.

Medlin, L. K., Barker, G. L. A., Campbell, L., Green, J. C., Hayes, P. K., Marie, D., Wrieden, S., and Vaulot, D.: Genetic characterisation of Emiliania huxleyi (Haptophyta), J. Marine Syst., 9, 13-31, https://doi.org/10.1016/0924-7963(96)00013-9, 1996.

Menschel, E., González, H. E., and Giesecke, R.: Coastaloceanic distribution gradient of coccolithophores and their role in the carbonate flux of the upwelling system off Concepción, Chile $\left(36^{\circ} \mathrm{S}\right)$, J. Plankton Res., 38, 798-817, https://doi.org/10.1093/plankt/fbw037, 2016.

Mix, A. C., Morey, A. E., Pisias, N. G., and Hostetler, S. W.: Foraminiferal faunal estimates of paleotemperature: Circumventing the No-analog problem yields cool Ice Age tropics, Paleoceanography, 14, 350-359, https://doi.org/10.1029/1999PA900012, 1999.

Mohan, R., Mergulhao, L. P., Guptha, M. V. S., Rajakumar, A., Thamban, M., AnilKumar, N., Sudhakar, M., and Ravindra, R.: Ecology of coccolithophores in the Indian sector of the Southern Ocean, Mar. Micropaleontol., 67, 30-45, https://doi.org/10.1016/j.marmicro.2007.08.005, 2008.

Murphy, E. J.: Spatial structure of the Southern Ocean ecosystem: predator-prey linkages in the Southern Ocean food webs, J. Anim. Ecol., 64, 333-347, 1995.

Nishida, S.: Nanoplankton flora in the Southern Ocean, with special reference to siliceous varieties, Memoirs of the National Institute for Polar Research, 40, 56-68, 1986.

Nissen, C., Vogt, M., Münnich, M., Gruber, N., and Haumann, F. A.: Factors controlling coccolithophore biogeography in the Southern Ocean, Biogeosciences, 15, 6997-7024, https://doi.org/10.5194/bg-15-6997-2018, 2018.

O'Brien, C. J., Vogt, M., and Gruber, N.: Global coccolithophore diversity: Drivers and future change, Prog. Oceanogr., 140, 2742, https://doi.org/10.1016/j.pocean.2015.10.003, 2016.

Okada, H. and Honjo, S.: The distribution of oceanic coccolithophorids in the Pacific, Deep-Sea Res., 20, 355-374, https://doi.org/10.1016/0011-7471(73)90059-4, 1973.

Orsi, A. H., Whitworth III, T., and Nowlin Jr., W. D.: On the meridional extent and fronts of the Antarctic Circumpolar Current, Deep-Sea Res. Pt. I, 42, 641-673, https://doi.org/10.1016/09670637(95)00021-w, 1995.

Patil, S., Mohan, R., Shetye, S., and Gazi, S.: Phytoplankton abundance and community structure in the Antarctic polar frontal region during austral summer of 2009, Chin. J. Oceanol. Limn., 31, 21-30, https://doi.org/10.1007/s00343-013-1309-x, 2013.

Patil, S. M., Mohan, R., Shetye, S., Gazi, S., and Jafar, S.: Morphological variability of Emiliania huxleyi in the Indian sector of the Southern Ocean during the aus- tral summer of 2010, Mar. Micropaleontol., 107, 44-58, https://doi.org/10.1016/j.marmicro.2014.01.005, 2014.

Pierrot, D., Lewis, E., and Wallace, D. W. R.: MS Excel Program Developed for $\mathrm{CO}_{2}$ System Calculations. ORNL/CDIAC-105a, Carbon Dioxide Information Analysis Center, Oak Ridge National Laboratory, U.S. Department of Energy, Oak Ridge, Tennessee, 2006.

Pollard, R. T., Bathmann, U., Dubischar, C., Read, J. F., and Lucas, M.: Zooplankton distribution and behaviour in the Southern Ocean from surveys with a towed Optical Plankton Counter, Deep-Sea Res. Pt. II, 49, 3889-3915, https://doi.org/10.1016/S0967-0645(02)00116-9, 2002.

Post, E., Bhatt, U. S., Bitz, C. M., Brodie, J. F., Fulton, T. L., Hebblewhite, M., Kerby, J., Kutz, S. J., Stirling, I., and Walker, D. A.: Ecological Consequences of Sea-Ice Decline, Science, 341, 519-524, https://doi.org/10.1126/science.1235225, 2013.

Poulton, A. J., Painter, S. C., Young, J. R., Bates, N. R., Bowler, B., Drapeau, D., Lyczsckowski, E., and Balch, W. M.: The 2008 Emiliania huxleyi bloom along the Patagonian Shelf: Ecology, biogeochemistry, and cellular calcification, Global Biogeochem. Cy., 27, 1023-1033, https://doi.org/10.1002/2013gb004641, 2013.

Riebesell, U., Zondervan, I., Rost, B., Tortell, P. D., Zeebe, R. E., and Morel, F. M. M.: Reduced calcification of marine plankton in response to increased atmospheric $\mathrm{CO}_{2}$, Nature, 407, 364-367, https://doi.org/10.1038/35030078, 2000.

Rigual Hernández, A. S., Flores, J. A., Sierro, F. J., Fuertes, M. A., Cros, L., and Trull, T. W.: Coccolithophore populations and their contribution to carbonate export during an annual cycle in the Australian sector of the Antarctic zone, Biogeosciences, 15, 1843-1862, https://doi.org/10.5194/bg-15-1843-2018, 2018.

Rivero-Calle, S., Gnanadesikan, A., Del Castillo, C. E., Balch, W. M., and Guikema, S. D.: Multidecadal increase in North Atlantic coccolithophores and the potential role of rising $\mathrm{CO}_{2}$, Science, 350, 1533-1537, https://doi.org/10.1126/science.aaa8026, 2015.

Saavedra-Pellitero, M. and Baumann, K. H.: Comparison of living and surface sediment coccolithophore assemblages in the Pacific sector of the Southern Ocean, Micropaleontology, 61, 507-520, 2015.

Saavedra-Pellitero, M. and Baumann, K.-H.: Calcification and distribution of extant coccolithophores across the Drake Passage during late austral summer 2016, PANGAEA, https://doi.org/10.1594/PANGAEA.901294, 2019.

Saavedra-Pellitero, M., Baumann, K.-H., Flores, J.-A., and Gersonde, R.: Biogeographic distribution of living coccolithophores in the Pacific sector of the Southern Ocean, Mar. Micropaleontol., 109, 1-20, https://doi.org/10.1016/j.marmicro.2014.03.003, 2014.

Samtleben, C. and Schröder, A.: Living coccolithophore communities in the Norwegian-Greenland Sea and their record in sediments, Mar. Micropaleontol., 19, 333-354, https://doi.org/10.1016/0377-8398(92)90037-K, 1992.

Saruwatari, K., Satoh, M., Harada, N., Suzuki, I., and Shiraiwa, Y.: Change in coccolith size and morphology due to response to temperature and salinity in coccolithophore Emiliania huxleyi (Haptophyta) isolated from the Bering and Chukchi seas, Biogeosciences, 13, 2743-2755, https://doi.org/10.5194/bg-132743-2016, 2016. 
Schlitzer, R.: Ocean Data View, available at: https://odv.awi.de/ (last access: 26 April 2019), 2015.

Smith, H. E. K., Tyrrell, T., Charalampopoulou, A., Dumousseaud, C., Legge, O. J., Birchenough, S., Pettit, L. R., Garley, R., Hartman, S. E., Hartman, M. C., Sagoo, N., Daniels, C. J., Achterberg, E. P., and Hydes, D. J.: Predominance of heavily calcified coccolithophores at low $\mathrm{CaCO}_{3}$ saturation during winter in the Bay of Biscay, P. Natl. Acad. Sci. USA, 109, 8845-8849, https://doi.org/10.1073/pnas.1117508109, 2012.

Supraha, L., Ljubesic, Z., Mihanovic, H., and Henderiks, J.: Observations on the life cycle and ecology of Acanthoica quattrospina Lohmann from a Mediterranean estuary, Journal of Nannoplankton Research, 34, 49-56, 2014.

Thomsen, H. A.: Identification by electron-microscopy of nanoplanktonic coccolithophorids (Prymnesiophyceae) from West Greenland, including the description of Papposphaera sarion sp. nov., Brit. Phycol. J., 16, 77-94, https://doi.org/10.1080/00071618100650071, 1981.

Thomsen, H. A. and Østergaard, J. B.: Coccolithophorids in Polar Waters: Wigwamma spp. Revisited, Acta Protozool., 52, 237256, https://doi.org/10.4467/16890027AP.14.022.1997, 2013.

Thomsen, H. A. and Østergaard, J. B.: Coccolithophorids in Polar Waters: Pappomonas spp. Revisited, Acta Protozool., 53, 235256, https://doi.org/10.4467/16890027AP.14.022.1997, 2014.

Triantaphyllou, M. V., Baumann, K.-H., Karatsolis, B.-T., Dimiza, M. D., Psarra, S., Skampa, E., Patoucheas, P., Vollmar, N. M., Koukousioura, O., Katsigera, A., Krasakopoulou, E., and Nomikou, P.: Coccolithophore community response along a natural $\mathrm{CO}_{2}$ gradient off Methana (SW Saronikos Gulf, Greece, NE Mediterranean), PLOS ONE, 13, e0200012, https://doi.org/10.1371/journal.pone.0200012, 2018.

van Bleijswijk, J., van der Wal, P., Kempers, R., Veldhuis, M., Young, J. R., Muyzer, G., de Vrind-de Jong, E., and Westbroek, P.: Distribution of two types of Emiliania huxleyi (Prymnesiophyceae) in the northeast Atlantic region as determined by immunofluorescence and coccolith morphology, J. Phycol., 27, 566-570, https://doi.org/10.1111/j.0022-3646.1991.00566.x, 1991.
Verbeek, J. W.: Recent Calcareous Nannoplankton in the Southernmost Atlantic, Polarforschung, 59, 45-60, 1989.

Verbeek, J. W.: Late Quaternary calcareous nannoplankton biostratigraphy for the northern Atlantic Ocean, Mededelingen Rijks Geologische Dienst, 44, 13-33, 1990.

von Dassow, P., Díaz-Rosas, F., Bendif, E. M., Gaitán-Espitia, J.-D., Mella-Flores, D., Rokitta, S., John, U., and Torres, R.: Over-calcified forms of the coccolithophore Emiliania huxleyi in high- $\mathrm{CO}_{2}$ waters are not preadapted to ocean acidification, Biogeosciences, 15, 1515-1534, https://doi.org/10.5194/bg-151515-2018, 2018.

Wassmann, P., Duarte, C. M., AgustÍ, S., and Sejr, M. K.: Footprints of climate change in the Arctic marine ecosystem, Glob. Change Biol., 17, 1235-1249, https://doi.org/10.1111/j.13652486.2010.02311.x, 2011.

Winter, A., Henderiks, J., Beaufort, L., Rickaby, R. E. M., and Brown, C. W.: Poleward expansion of the coccolithophore Emiliania huxleyi, J. Plankton Res., 36, 316-325, https://doi.org/10.1093/plankt/fbt110, 2014.

Young, J. R. and Westbroek, P.: Genotypic variation in the coccolithophorid species Emiliania huxleyi, Mar. Micropaleontol., 18, 5-23, https://doi.org/10.1016/0377-8398(91)90004-P, 1991.

Young, J. R. and Bown, P.: Higher classification of calcareous nannofossils, Journal of Nannoplankton Research, 19, 15-20, 1997.

Young, J. R., Geisen, M., Cros, L., Kleijne, A., Sprengel, C., Probert, I., and Østergaard, J.: A guide to extant coccolithophore taxonomy, Journal of Nannoplankton Research, 1, 125 pp., 2003.

Young, J. R., Bown, P. R., and Lees, J. A.: Nannotax3 website, International Nannoplankton Association, available at: http://www. mikrotax.org/Nannotax3, last access: April 2019. 